The Phylogeny and Classification of the Diseae (Orchidoideae: Orchidaceae)

Author(s): H. P. Linder and H. Kurzweil

Source: Annals of the Missouri Botanical Garden, Vol. 81, No. 4 (1994), pp. 687-713

Published by: Missouri Botanical Garden Press

Stable URL: http://www.jstor.org/stable/2399916

Accessed: 27-07-2016 11:10 UTC

Your use of the JSTOR archive indicates your acceptance of the Terms \& Conditions of Use, available at

http://about.jstor.org/terms

JSTOR is a not-for-profit service that helps scholars, researchers, and students discover, use, and build upon a wide range of content in a trusted digital archive. We use information technology and tools to increase productivity and facilitate new forms of scholarship. For more information about JSTOR, please contact support@jstor.org.

Missouri Botanical Garden Press is collaborating with JSTOR to digitize, preserve and extend access to Annals of the Missouri Botanical Garden 


\title{
THE PHYLOGENY AND CLASSIFICATION OF THE DISEAE (ORCHIDOIDEAE: ORCHIDACEAE) ${ }^{1}$
}

\begin{abstract}
The subtribal classification of the Diseae (Orchidoideae) is reviewed in light of the available morphological, leaf anatomical, and palynological data. These data are critically assessed, and the more prominent features are illustrated. The data are analyzed cladistically, and the robustness of the various components of the most parsimonious tree is assessed by a bootstrap analysis. Based on the cladistic analysis and the bootstrap analysis, a new classification is proposed for the Diseae. The results of the bootstrap analysis are used to establish the nodes at which formal taxa should be recognized. This classification recognizes five monophyletic subtribes: the Satyriinae, Disinae, Brownleeinae (a new subtribe), Huttonaeinae, and Coryciinae. It is suggested that Brownleea, the only genus of the Brownleeinae, may be of hybrid origin, as it shares the autapomorphies of the Disinae and Coryciinae. Huttonaea is shown to be more closely related to the Diseae than to the Orchideae, and is consequently included as a subtribe of the Diseae. The new classification is formally presented, and a key to the genera is provided.
\end{abstract}

The Diseae are a tribe of largely terrestrial African orchids, which include the spectacular Disa uniflora Bergius, the morphologically complicated subtribe Coryciinae, and the striking Huttonaea grandiflora (Schltr.) Rolfe. There are several subtribal classifications available, none of which have been carefully substantiated in terms of their character support. While some of these subtribal groupings may be monophyletic, recent data indicate that several genera are probably misplaced, rendering other groups paraphyletic.

The taxonomy at the species level has been completely revised for all taxa excluding the extraSouth African species of Disperis and Satyrium, and even for these genera several local revisions have been produced recently. In both the subtribes Coryciinae (Kurzweil et al., 1991) and Disinae (Linder, 1986; Linder \& Kurzweil, 1990), there have been attempts at reviewing the generic classification. But there are several indications that the subtribal classification may not be as sound as suggested by Linder (1986). A study of Huttonaea (Kurzweil, 1989) indicates certain affinities to the Coryciinae, and a recent study on Brownleea (Linder \& Kurzweil, in prep.) suggests the same.

The first attempt to subdivide the Orchidoideae (tribe Ophrydeae of Lindley, 1830-1840) was by
Bentham in Bentham \& Hooker (1883), who recognized four subtribes: Euophrydeae (Serapieae), Habenarieae, Diseae, and Corycieae. The former two are not being considered here. The Corycieae are identical to the Coryciinae, Disperideae, or Disperidinae recognized by Pfitzer (1889), Kraenzlin (1899-1900), Schlechter (1898), Rolfe (19121913), Senghas (1973-1974), and Dressler (1981). They defined the Corycieae as having adnate petals and dorsal sepals, with lips fused to the gynostemium bases and often appendiculate, and included Pterygodium, Corycium, Ceratandra, and Disperis in the subtribe. The only changes over the past century to this group have been in the delimitation of the genera (for a review and phylogenetic classification, see Kurzweil et al., 1991).

The Diseae of Bentham \& Hooker (1883) have had a more complicated history. The authors defined this subtribe by its reflexed anther and the large, subterminal stigma. They included the modern Satyriinae (Senghas, 1973-1974; Dressler, 1981), Disinae (Senghas, 1973-1974; Dressler, 1981), as well as three genera of the Orchideae (Brachycorythis, Schizochilus, and Platycoryne) in the subtribe. Pfitzer (1889) substantially followed Bentham and Hooker, but named the group the Satyrieae. Kraenzlin (1899-1900) removed the

\footnotetext{
' Supported by the Foundation for Research Development, Pretoria, South Africa. The second author also acknowledges the support of the Smuts Memorial Fellowship.

${ }^{2}$ Bolus Herbarium, University of Cape Town, Rondebosch 7700, South Africa.

${ }^{3}$ Current address: Compton Herbarium, National Botanical Institute, Kirstenbosch, P. Bag x 7, Claremont 7735, South Africa.
}

AnN. Missouri Bot. Gard. 81: 687-713. 1994. 
TABLE 1. A comparison of the tribal and subtribal classifications of the Diseae sensu lato.

\begin{tabular}{|c|c|c|c|c|c|}
\hline Bentham \& Hooker (1883) & & Diseae & & & Corycieae \\
\hline Pfitzer (1889) & & Satyrieae & & & Corycieae \\
\hline Rolfe (1912-1913) & & Diseae & & & Corycieae \\
\hline Schlechter (1927) & & Disaeinae & & & Disperidinae \\
\hline Schlechter (1926) & Satyrieae & & Diseae & & Disperideae \\
\hline Senghas (1973-1974) & Satyrieae & & & Diseae & \\
\hline \multirow{3}{*}{ Dressler (1981) } & Satyrïnae & & Disinae & & Disperidinae \\
\hline & & & Diseae & & \\
\hline & Satyrïnae & & Disinae & & Coryciinae \\
\hline
\end{tabular}

last three genera and placed them, in our opinion, in their correct groupings. This narrower definition of the group was followed by all subsequent authors (Schlechter, 1901; Rolfe, 1912-1913; Senghas, 1973-1974; Dressler, 1981). As Bentham \& Hooker's definition of the subtribe is uncannily accurate, their inclusion of these three genera in the Diseae must have been based on inaccurate morphological information. The recognition that there are two subgroups within the Diseae (sensu Schlechter and Rolfe) finds expression in the formal recognition of separate groups (Senghas, 19731974; Dressler, 1981).

The first suggestion to combine the Satyrïnae, Disinae, and Coryciinae into a single tribe, the Diseae, was by Dressler (1979), but has not been accepted by Szlachetko (1991). Other authors used every single combination possible: these are summarized in Table 1.

Huttonaea has had a checkered history. Bentham \& Hooker (1883) placed the genus between Bartholina and Holothrix in the Habenarieae, while Pfitzer (1889) and Kraenzlin (1899-1900) included the genus in the section Gymnadenieae. This approach was followed by Rolfe (1912-1913). Senghas (1973-1974) and Dressler (1981) separated Huttonaea into its own subtribe in the Orchideae, the Huttonaeinae, and noted that it had no close relatives. They placed it in the Orchideae because of its apparently erect anther.

The delimitation of the genera in the tribe has been a persistent problem, and different treatments vary greatly. The original generic delimitations were established by Swartz (1800), and were further elaborated on by Lindley (1830-1840). Subsequent students of the group have generally erected smaller and smaller genera, a tendency that finally culminated in the large number of small genera upheld by Rolfe (1912-1913) in the Flora Capensis. This system, however, did not result in a phylogenetically sound classification, as the core paraphyletic genera were retained, and some of the segregated genera were polyphyletic groups based on flower resupination and other striking features. In this way Rolfe upset the more synthetic approach of Schlechter (1901), who recognized very wide genera that were generally monophyletic. The generic limits in the Coryciinae were recently assessed by Kurzweil et al. (1991), and detailed arguments on the monophyly of the genera are presented there. The subtribe Disinae still presents a problem. Lindley (1830-1840) already commented on the difficulty of establishing groups within the broad genus Disa, and all attempts at establishing an empirically sound generic classification have failed (Rolfe, 1912-1913; Schelpe, 1966; Linder, 1981a-f, 1986; Linder \& Kurzweil, 1990). Although the presently recognized segregate genera are clearly monophyletic, their relationship to the large core genus Disa is not clear, and it is certain that the recognition of a distinct genus Herschelianthe renders Disa paraphyletic. In this treatment the genera as established by Linder (1986) are used, despite the clear evidence that Disa is paraphyletic. The generic limits in the subtribe Satyriinae have not yet benefitted from a detailed study. However, Linder (1989) demonstrated the monophyly of Satyrium relative to $S a$ tyridium and showed that both can be upheld. The genus Pachites, which comprises two species, is poorly known, due to its great rarity, but there is unpublished information that casts doubt on the monophyly of the genus (Kurzweil, unpublished data), and consequently we treat the two species separately here.

These classifications have been heavily based on floral morphology. However, until recently the floral morphology in this group of orchids has been rather poorly understood. The flowers of tribe $\mathrm{Di}$ seae are very complicated and difficult to interpret (Dressler, 1981). Individual species were studied in detail by Trimen (1864), Weale (1873), Bolus (1882), and Marloth (1895), but these authors mainly concentrated on species of subtribe Disinae and their pollination. The first comprehensive description of the flowers of a large number of species 
was that of Harry Bolus in his floristic accounts (Bolus, 1888, 1893-1896, 1911, 1913, 1918). Further morphological knowledge was contributed in the floristic and taxonomic studies of Schlechter (1898, 1901) and Rolfe (1898, 1912-1913). The exhaustive study of Vogel (1959) on the floral morphology of various species was frequently regarded as providing the final explanation for the odd flower structures in this group. However, due to the lack of ontogenetic investigations certain structures were misinterpreted. Morphologically significant genera were not dealt with and, consequently, several questions remained unaddressed. In the past five years there has been substantial progress in the knowledge of the morphology and ontogeny of the flowers of the Diseae. Kurzweil (1990) described the Disinae, Kurzweil et al. (1991) and Kurzweil (1991) the Coryciinae, Kurzweil \& Linder (1991) some of the Disperis species, and Linder \& Kurzweil (in prep.) Brownleea. In addition, Kurzweil (1989) described the morphology of Huttonaea in great detail. Further sources of information have been investigated: Chesselet \& Linder (1993) studied the pollinium ultrastructure and Chesselet (1989) reported on the leaf anatomy of the Disinae and Coryciinae. We have extensive unpublished data for the Satyriinae. There are, however, several structures that have not yet been adequately investigated. These include the chromosome complement and the anatomy of the rootstem tuberoids.

The available data suggest that a careful reconsideration of the suprageneric classification of the tribe Diseae is required. In this study a cladistic analysis of all available data is presented, on which a sound phylogenetic classification for the group can be based.

\section{METHODS}

Morphological, anatomical, and palynological data were collected from various publications, and in critical cases new observations were made from the herbarium and pickled collections held at the Bolus Herbarium, University of Cape Town. Vouchers are given in the figure captions. These data were then studied comparatively, scored for the genera, and a maximum parsimony analysis performed, using the "ie*" routine in the Hennig86 (Farris, 1988) cladistic analysis software package. The data were outgrouped to a set of genera belonging to the Orchideae, which differ in the possession of a spurred lip. In order to locate a single more resolved tree, successive weighting was applied (Farris, 1969; Carpenter, 1988). The individual character consistency indices for the three fundamental trees were averaged and used to calculate a weighting for each character, on a scale from 0 to 10 . Then the parsimony analysis was rerun to locate the most parsimonious tree. The procedure was repeated until the cladogram stabilized. To test the support for the different monophyletic groups, and the confidence with which they may be proposed, the data set was randomly sampled 100 times, and the analyses rerun (Felsenstein, 1985; Sanderson, 1989; Linder, 1991). For each random sample the consensus tree was calculated from the complete set of shortest equal length trees located by using the "ie*" routine in Hennig86. This was necessary to locate a single tree for each sample to determine the frequency occurrence of each component, a routine which is not explicit in PAUP Version 3.1 (Swofford, 1993). These 100 consensus trees were then scanned, and the frequency of occurrence of each of the components of the most parsimonious tree determined. Although this procedure approximates the "bootstrap" methods of Felsenstein (1985), as implemented by Swofford (1993), it differs in that the components of a selected topology are tested directly, rather than indirectly, by the calculation of a $50 \%$ majority rule consensus tree from the set of sampled data sets. Although these analyses do not produce a valid statistical test of the confidence limits for the cladogram (Linder, 1991; Werdelin, 1989), they do give a rough indication of the support implicit in the data set used for each node. The methods used are described by Linder (1991) and Sanderson (1989).

The coding of variable taxa poses some problems. Some of these problems may be due to the terminal groups not being monophyletic, and so incorporating more variation than they should. However, most of the genera have been tested critically for their monophyly (see above) and where there was doubt the problem is clearly delimited (such as in the Disinae), or the genus is broken into its components (such as in Pachites). Where monophyletic taxa are variable, there are two ways of coding the variation. If the ancestral condition for the genus has been determined by a cladistic analysis of its species such as in Brownleea (Linder \& Kurzweil, in prep.) or in the Coryciinae sensu stricto (Kurzweil et al., 1991), this condition is coded for the terminal taxon, because we are interested in the character description of the ancestor of the terminal unit. Where this detailed information is not available, the character is coded as unknown (?) for the genus. Characters for which the evolutionary polarity could not be determined by outgroup comparison because they occur in a small subset of the taxa, but for which ontogenetic 


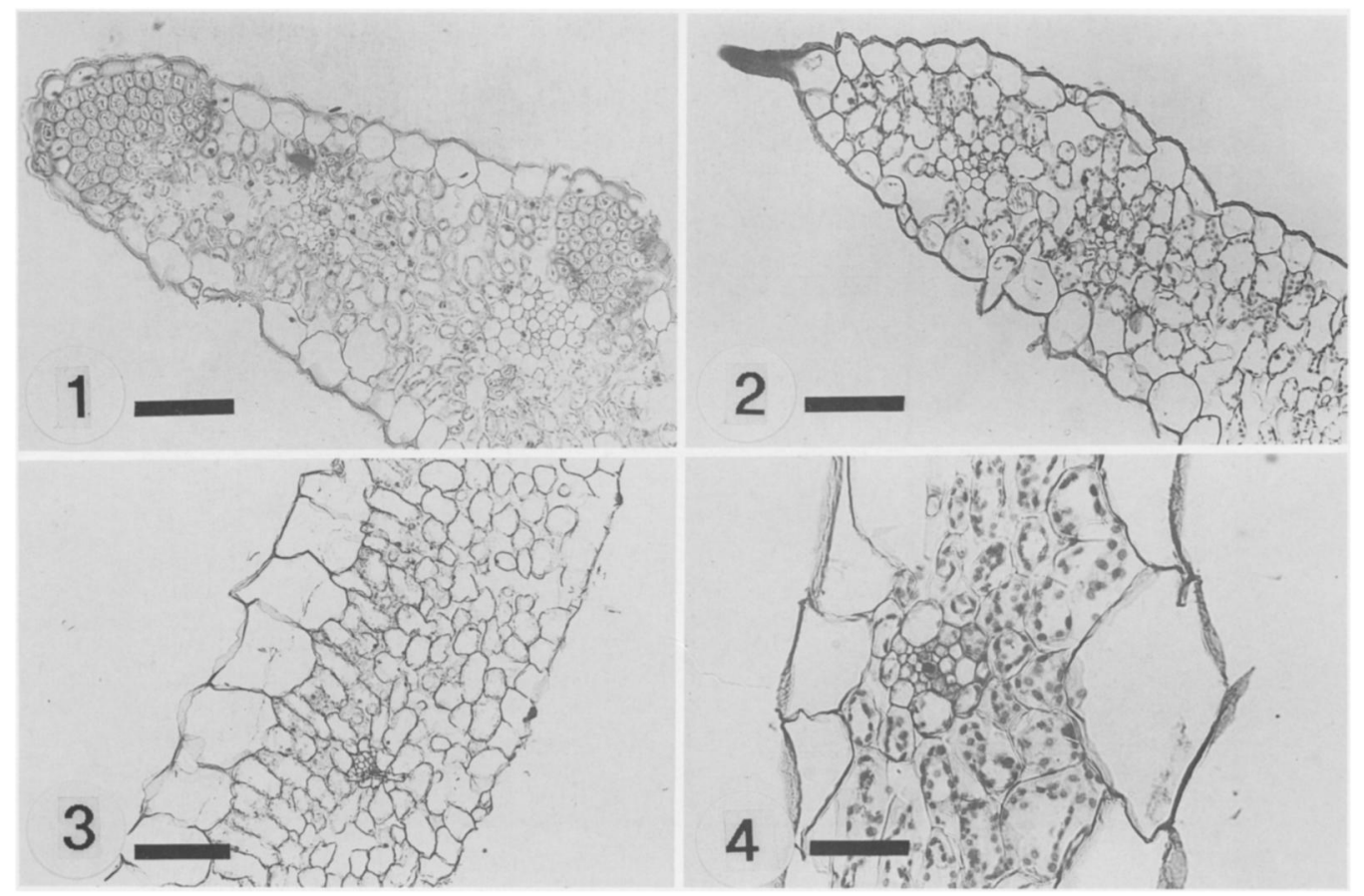

Figures 1-4. Leaf anatomy of the Diseae. Scale bar: $50 \mu \mathrm{m} .-1$. Disa oreophila H. Bolus; note large sclerifed caps on the vascular bundles. - 2. Ceratandra atrata (L.) T. Durand \& Schinz; note bristle on leaf margin and small sclerenchyma caps associated with the vascular bundles. - 3. Disa pillansii L. Bolus; note the differences between the adaxial (on the left side) and abaxial epidermis, and the well-developed palisade layer. -4. Pterygodium alatum (Thunb.) Swartz, with the two epidermises similar, and without a mesophyll palisade. Vouchers (PC = P. Chesselet; $\mathrm{L}=$ H. P. Linder). 1: L 3663, 2. PC 26, 3. PC 22, 4. L. 4747.

data were available, were coded in taxa where the character is missing to reflect the polarity inferred from the ontogenetic data. In several cases a character may be present in the majority of the species, but absent in a few. Where these species are known to be closely related to species with the character, this variation was, as suggested by Stevens (1991), ignored.

\section{MORPHOLOGY}

\section{VEGETATIVE MORPHOLOGY}

There is little variation in the vegetative morphology in the tribe. In Ceratandra the perennating organs are swollen roots, while in the remaining genera they are testicular root-stem tuberoids. The only exceptions are some species in Disa (Linder, 1981c) in which the tubers may be lost, and the plants propagate by vegetative stolons. In these species there is often a perennial aboveground leafy cover. Although there is variation in the vascularization of the root-stem tuberoids (pers. obs.), the homologies and basic structure of the root-stem tuberoids are at present inadequately understood to interpret the variation, and the database is also still too incomplete.

The leaf anatomy of the Diseae was surveyed by Chesselet (1989) and Kurzweil (in prep.). Although individual species may have very different leaf anatomies (Figs. 1-4), these appear to be homoplasious, and there is no consistent pattern across the tribe. Some genera, like Herschelianthe or Ceratandra, have distinctive leaf anatomies, but there are no features that combine genera. This

Figures 5-10. Habit and inflorescence structure of various species in the tribe. Scale bars: $5 \mathrm{~cm} .-5$. Disa cornuta (L.) Sw.; note robust many-flowered infloresence. -6. Huttonaea fimbriata Rchb. f., inflorescence sparse, leaves broad. - 7. Brownleea macroceras Sond., inflorescence of 1-2 flowers. -8. Ceratandra grandiflora Lindl., many-flowered inflorescence contracted into an almost capitate head. - 9. Pterygodium leucanthum $\mathrm{H}$. Bolus, relatively sparse inflorescence.-10. Satyrium candidum Lindl., robust, many-flowered inflorescence. Sources (HK $=\mathbf{H}$. Kurzweil). 5: HK s.n., 6: HK 1599, 7: HK 1576, 8: HK 1226, 9: HK 1641, 10: Jackson s.n. 

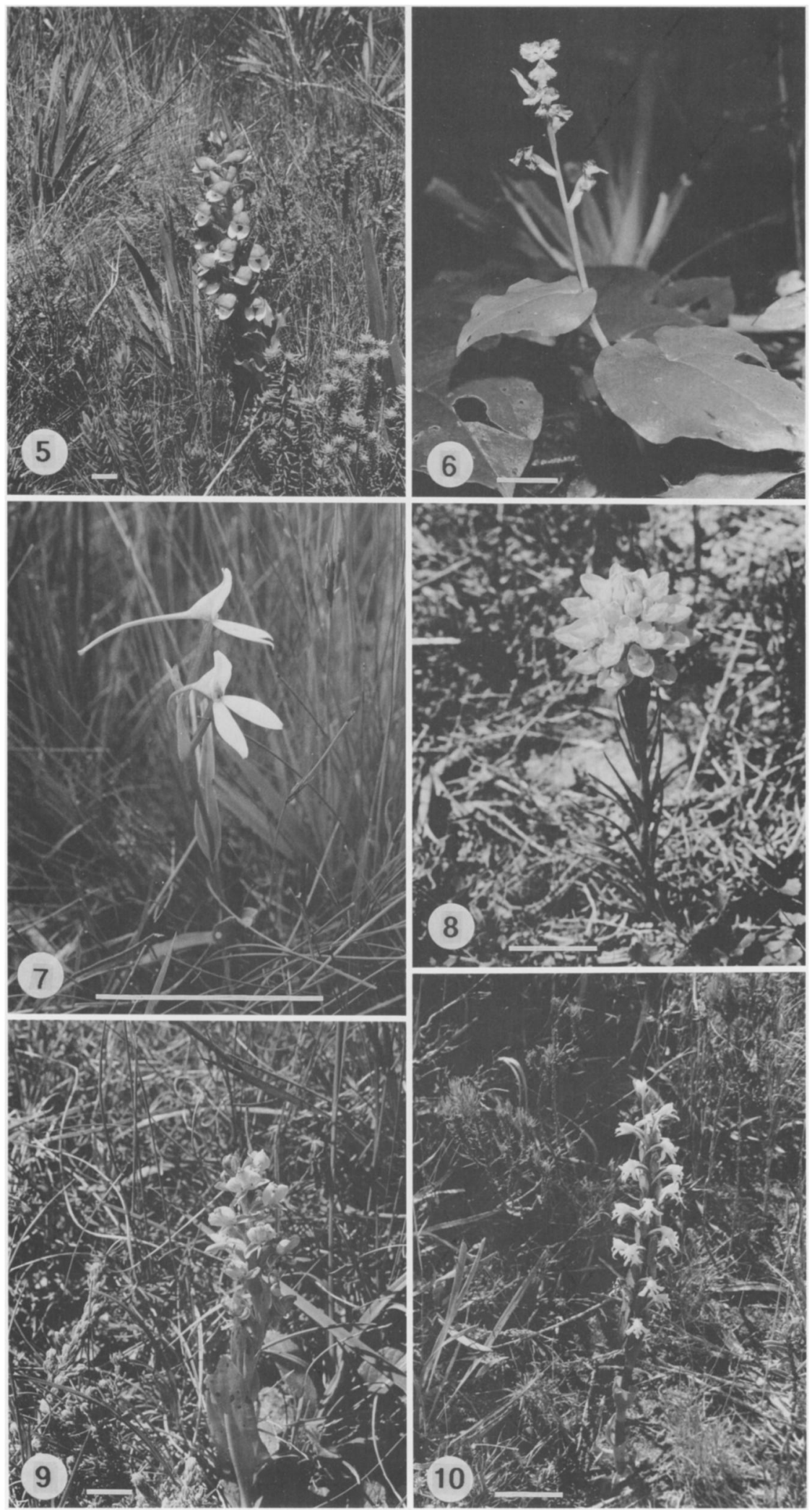
may not apply in the case of the sclerified leaves of Herschelianthe, but the relationship with Disa is not clear, and similar leaves occur in some sections of Disa (Fig. 1). The occurrence of hysteranthy may be related to the anatomy and texture of the leaves and floral bracts, but this variation is also restricted to within the Disinae, and cannot be properly interpreted until the phylogeny within this subtribe is better understood (Linder \& Kurzweil, 1990).

\section{INFLORESCENCES}

The inflorescences are simple racemes, which vary from many- to single-flowered (Figs. 5-10). However, in most genera some species have numerous flowers, which makes the polarization of this character difficult. It appears likely that a many-leaved, many-flowered plant (e.g., Fig. 5) is the plesiomorphic condition, and, as this occurs in virtually all genera, this does not provide any phylogenetic information above the generic level (see also the discussion on this character in Kurzweil et al., 1991).

\section{SEPALS}

The involvement of the sepals in the attractive organs of the flower may contain some phylogenetic information. In the Disinae and Satyrium the lateral sepals are brightly colored, and may be the largest and most brightly colored floral organs (Figs. $11,12,15,20,21$ ), while in the Coryciinae sensu stricto (Coryciinae excluding Disperis, see Kurzweil et al., 1991) they are green and generally insignificant (Figs. 16, 17, 18). The modification of the sepals to become part of the attraction system of the flowers is difficult to quantify, especially when the flowers are green. Green flowers, in which the sepals differ in texture from the bracts, are also considered modified.

In Disinae the sepals, and sometimes even the petals, are apiculate (Fig. 12). These apicules develop very early in the ontogeny of these parts, and in some species may be very well developed (e.g., Disa telipogonis Reichb. f.), although in others they may be obscure (e.g., most species in Monadenia). These apicules may be remnants of the unifacial tip of the general monocotyledon leaf structure, consisting of a unifacial tip and bifacial sheath (Kaplan, 1975; Weber, 1980; Rudall, 1990), with the blade developed from either or both of them. Vogel (1959) interpreted the sepals as being homologous to the bifacial sheath and the unifacial tips the remnants of the leaf blades. However, such apicules are absent in the rest of the Diseae, but occur sporadically in many diverse orchid groups. Their polarization is therefore difficult, as theoretically they would be primitive features, but outgroup comparison to the Orchideae indicates that they are synapomorphic for the Disinae.

The lateral sepals are generally unspecialized ligulate to ovate structures (Figs. 1 1-22). In some genera they contain important autapomorphic characters, or characters that delimit groups within the genera. In Disperis the lateral sepals have short conical spurs (Fig. 19), while in Corycium they are often papery, and may be partially fused (Fig. 17).

The dorsal sepal is unspecialized (e.g., without peculiar modifications) in the Satyriinae (Figs. 2022), Huttonaea (Figs. 13, 14), and the Coryciinae sensu stricto (Figs. 16-18), but differs in the other genera. In the Disinae (Figs. 11, 12) and in some species of Disperis the dorsal sepal is galeate. A spurred dorsal sepal is supposed to be diagnostic for the Disinae, but there are some species without spurs, although these are usually very similar to spurred species (Linder, 1981c, e; Linder \& Kurzweil, 1990). It is therefore assumed that the spurs were lost secondarily, and all the genera of the Disinae are coded as having spurred dorsal sepals,

FiguREs 11-22. Flowers of various Diseae. Scale bars: $5 \mathrm{~mm} .-11$. Disa erubescens Rendle; note the large sepals and the narrowly linear lip.-12. Herschelianthe graminifolia (Ker Gawl. ex Spreng.) Rauschert; note the broad, ovate lip and the large galeate dorsal sepal. - 13. Huttonaea grandiflora (Schltr.) Rolfe, with a fimbriate lip and petals. - 14. Huttonaea pulchra Harv., with spathulate fimbriate petals. - 15. Brownleea macroceras Sond., with the large lateral sepals and the petals adnate to the dorsal sepal to form the galea.-16. Ceratandra atrata (L.) T. Durand \& Schinz, with the lateral sepals arching forward and the large hornlike anther thecae.-17. Corycium crispum (Thunb.) Sw.; note the large galea constructed largely of the petals.-18. Pterygodium inversum (Thunb.) Sw. with a large galea constructed largely from the petals; note that in this species the flowers are not resupinate.19. Dispersis paludosa Harv.; note the spurred lateral sepals. - 20. Satyrium erectum Lindl., with the lip modified into a two-spurred galea, and the petals and sepals forming the landing platform at the entrance to the galea. -21 . Satyrium odorum Sond., showing the entrance to the galeate lip, with the upper margin recurved.-22. Pachites adpressa Lindl.; note the very simple perianth. Sources (HK = H. Kurzweil). 11: HK 1404, 12: HK 1069, 13: HK 1591, 14: HK 1623, 15: HK 1576, 16: Jackson s.n., 17: Jackson s.n., 18: Darling Wild Flower Show 1986, 19: Drewe s.n., 20: Jackson s.n., 21: HK 852, 22: Burger s.n. 

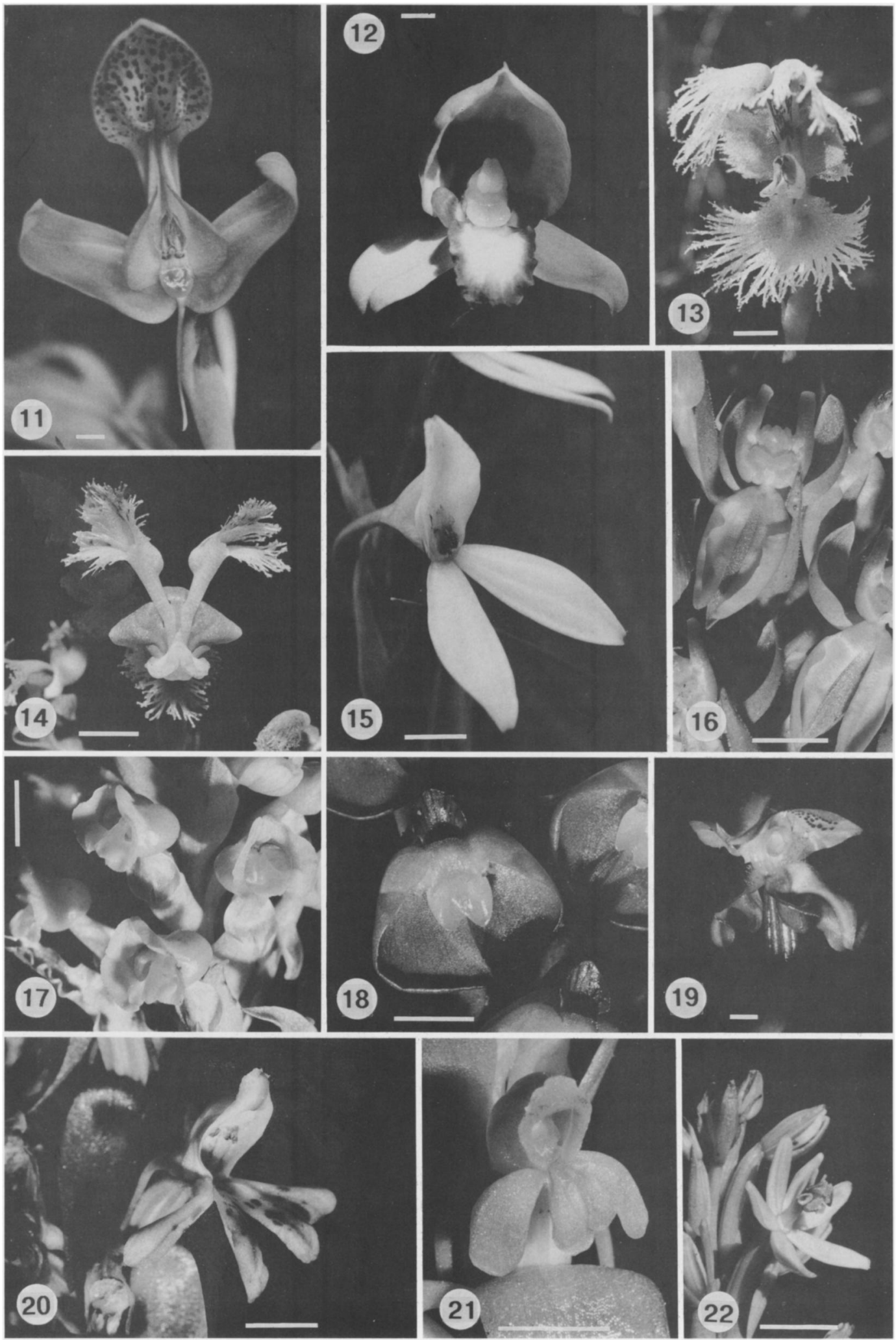
following the guidelines suggested by Stevens (1991). However, the situation is more complex in Disperis, where only a minority of the species bear dorsal sepal spurs. As there is as yet no general cladogram available for the genus, it cannot be inferred whether the presence or absence of spurs is ancestral, nor can the frequency of occurrence argument be used in this case, because it is not clear whether these spurs were lost secondarily or gained independently from the spurs in the Disinae. Disperis has therefore been coded as unknown for this character. In the rest of the Coryciinae, the dorsal sepal is not generally galeate and, although it may be concave and form a galea in combination with the petals, it is usually the smallest of the organs involved. It may be that once a deeply concave or galeate dorsal sepal evolves, the step toward a saccate or spurred structure is relatively small, and this may account for the parallel evolution of dorsal sepal spurs in the Disinae and in Disperis. Comparison with the cladogram would also indicate a parallel evolution in Brownleea, in which the dorsal sepal is a slender organ. This is an exception to the above theory. It is evident that spurred dorsal sepals evolved several times in the Diseae, and as this character has generally been stressed in the subtribal classifications, it may have contributed to the persistent misclassification of Brownleea.

\section{PETALS}

The petals are very variable in the tribe (Figs. $11-22$ ) and have been found useful at the infrageneric level in the Disinae (Linder, 1981a-e; Linder \& Kurzweil, 1990). In the Coryciinae and Brownleea the petals are adnate (postgenitally fused) to the dorsal sepal, and the three structures combine to form the galea (Figs. 15-19). This is also found to a lesser extent in the Orchideae, especially in Cynorkis. There is extensive variation in the degree of contribution of the petals and the dorsal sepal to the galea, especially in Disperis. In some species the petals are simple lorate to linear structures, with the dorsal sepal forming the bulk of the galea (Fig. 19), while in other species the dorsal sepal is a simple, linear structure, essentially only forming the keel of the galea, while the petals form the bulk of the hood (Figs. 17, 18).

In the Disinae and Brownleea the base of the petals is fused to the gynostemium. This fusion may be insignificant, or in Disa sect. Aconitoideae may be in the form of a prominent ridge. Kurzweil (1990) has substantiated Schlechter's (1901) opinion that the fusion keel is derived, at least partially, from staminodes. The presence of various lobes on the petals is useful at specific, sectional, and possibly in some cases generic level, but its presence is rather variable in most genera, making it of little use for suprageneric analysis. Basal anterior lobes have been used to define the sections in the large genus Disa (Linder, 1981c), and apically bilobed petals occur in the majority of the species of Disa sect. Micranthae (Linder, 1981f; Linder \& Kurzweil, 1990).

Huttonaea has very peculiar petals, which are clawed, with a saccate blade and a fimbriate margin (Figs. 13, 14). The apices of the fimbriae appear to be glandular (Kurzweil, 1989).

Biologically, the petals in the Disinae appear to function to direct the pollinator into the dorsal sepal spur, in the Coryciinae they form the galea, and in the Satyriinae they form part of the landing platform. The role of the fimbriate petals in Huttonaea is not clear, and it is possible that the glands offer a reward for the pollinator.

Frequently associated with this formation of the petals plus dorsal sepal galea is the presence of extraordinarily strongly developed petal nerves. The degree of development of such "petal nerves" is variable, and they are missing in many species. However, although such "petal nerves" have been recorded in various genera of other subfamilies of the orchids, they have a restricted distribution in

FIGURE 23. Variation in the gynostemium structure in the Diseae, showing only the gynostemium and lip. Cut surfaces are indicated by hatching, the viscidia are black; $\mathrm{a}=$ anther, $\mathrm{s}=$ stigma, $\mathrm{l}=\mathrm{lip}$ and $\mathrm{la}=\mathrm{lip}$ appendage. Scale bars: B, D, E, G: $1 \mathrm{~mm}$, A, C, F: $2 \mathrm{~mm}$. A, B. Pachites bodkinii H. Bolus.-A. Gynostemium and lip; note the long column-part and somewhat three-lobed lip.-B. Details of gynostemium apex, showing the reflexed anther, two rostellum lobes and the auricles at the apex of the rostellum lobes. C, D. Satyrium erectum Swartz. - C. Gynostemium and a half-section of the galeate lip, showing one of the two spurs. -D. Details of the gynostemium apex; note the flaplike stigma.-E. Disa tripetaloides (L.f.) N.E. Br., gynostemium with the horizontal lip, and showing the vertical scar where the petal was attached to the gynostemium.-F. Pterygodium acutifolium Lindl., showing the massive erect lip appendage, gynostemium with the anthers widely separated, and the viscidia carried to the sides of the lip. - G. Brownleea recurvata Sond., showing the lip broadly fused to the base of the stigma, with a narrow erect limb in front of the stigma, and the large fingerlike auricles. Sources. A, B, Burger s.n. C, D, Hall 1031. E, Linder 1670. F, Linder 1589. G, Linder 1767. 


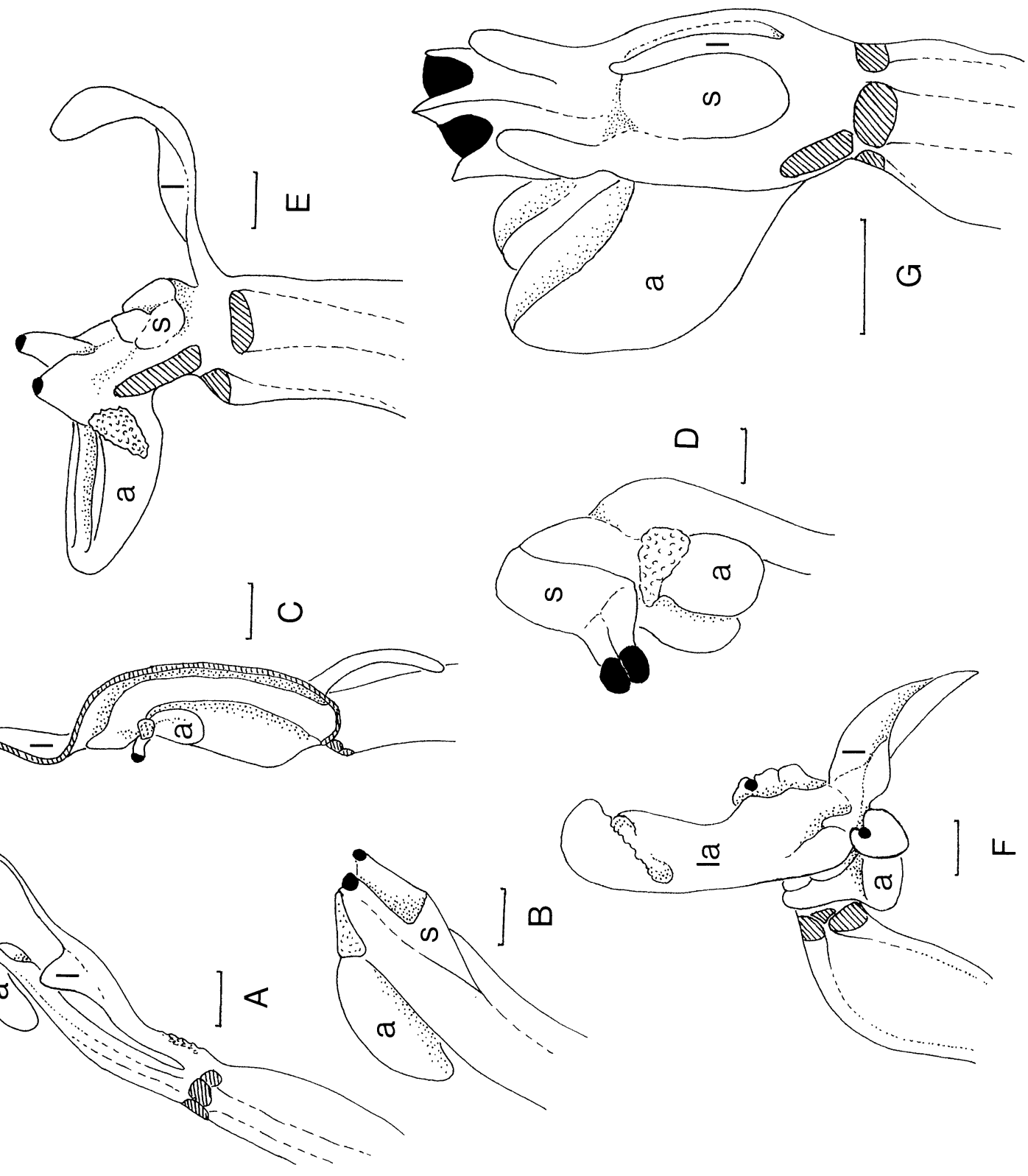


the Diseae, and may therefore be informative despite their occasional absence in some of the groups in which they occur. The polarization of the character on the tree is not unequivocal, as there have been three parallel gains in this character, as compared to four losses. The polarization has therefore been determined by the distribution of the character in the outgroup.

\section{LIP}

The lip is the most complex perianth member in most orchid groups. It usually makes the orchid flower zygomorphic and often has complex lobes and excrescences. Consequently it has been suggested (e.g., Darwin, 1888) that the lips are morphogenetically complex organs, consisting of an inner tepal and the staminodes. This hypothesis is no longer entertained because of the lack of supporting evidence (Dressler, 1981). Although the lip in the Diseae is enormously variable and often extraordinarily complex, it is very different from the "typical" orchid lip, in that it rarely shows three lobes, rarely has lip-calli, and never has a single median spur (Fig. 23).

The orientation of the lip is variable. In the Orchideae and in some groups of the Diseae the lip is orthotropous: it continues, at least at the base, in the same direction as the axis of the flower. This is particularly evident in the Orchideae with median spurs on the lips, where the spur is parallel to the ovary, and essentially in line with the lip blade. In the Satyriinae the lip is also orthotropous (Fig. 23C). In the Coryciinae and Brownleea the lip is also in line with the axis, at least at the base, where it is generally fused to the gynostemium (Fig. 23F, G). In the Disinae excluding Schizodium, however, the lip is reflexed at the base, so that it is held at right angles to the axis of the flower (Fig. 23E). A similar situation is found in Huttonaea (Figs. $13,14)$. In the Disinae the lip is a simple structure, without any outgrowths, usually without lobing, and not fused to any other organs (Fig. 11). It is usually a linear to lorate organ (e.g., Disa uniflora), although it may be rarely ovate (Disa ferruginea (Thunb.) Sw., Herschelianthe graminifolia (Ker Gawl. ex Spreng.) Rauschert, Fig. 12), variously lacerated (Herschelianthe barbata (L.f.) N.C. Anthony), clawed (Herschelianthe multifida (Lindl.) Rauschert), lobed (Herschelianthe spathulata (L. f.) Rauschert), or divided into a hypochile, mesochile, and epichile (Schizodium). In Satyrium (Figs. 20, 21 ) and Satyridium the lip is galeate and has two spurs. These spurs are obsolete or highly reduced in a few species, but these are almost certainly secondary losses, as the species concerned are clearly related to species with bi-spurred lips. In Pachites the lip is very simple, as in the Disinae, while in Huttonaea it is broad and fimbriate. In Brownleea the lip has a broad base which is fused to the base of the gynostemium, and a tiny linear blade which is erect in front of the rostellum (Fig. 23G).

The lip of the Coryciinae is truly complex. The blade is variable in shape, ranging from linear to triangular to three-lobed and from medium-sized to large. In Evotella and Ceratandra the lip blade is characteristically spathulate and anchor-shaped (Kurzweil et al., 1991). The base of the lip is almost always fused to the base of the gynostemium. The lip also bears an appendage that is found in the same position as the median adaxial stamen A3 (which is lost in orchids) (Fig. 23F), and this might suggest a derivation from such a staminode (Pfitzer, 1889). However, ontogenetic evidence obtained in various Coryciinae clearly suggests that the lip is of the same nature as the petals (Kurzweil, 1991). The peculiar lip appendage of the Coryciinae is initiated late in the ontogeny. Apparently, the lip appendage of the Coryciinae is merely an outgrowth of the lip as also found in numerous other orchids. This appendage is probably primitively bilobed (Kurzweil et al., 1991; Kurzweil \& Linder, 1991), but in many groups there is little trace of the bilobed origin, and in Corycium it forms a massive shield over the anther and rostellum (Kurzweil et al., 1991).

The function of the lip in the pollination biology is, like the petals, complex. In Satyrium and $S a$ tyridium it forms the hood and the spurs bearing the nectar; in the Disinae it forms part of the landing platform together with the lateral sepals, and in the Coryciinae it usually bears the oil-bearing attractant for the oil-gathering bees (Steiner, 1989).

\section{GYNOSTEMIUM}

The anther is basally reflexed in this group of orchids (Fig. 23). This reflection occurs very late in the ontogeny, directly before anthesis. However, there are exceptions to the rule of the reflexed anther. In Disa sect. Micranthae and Pterygodium sect. Ommatodium the anther is always erect, and there is no evidence of any reflection during ontogeny. In the case of Pterygodium sect. Ommatodium, Kurzweil et al. (1991) postulated that the erect anther is derived from a reflexed anther, and this was supported by their cladistic analysis. In Brownleea the anther is basally reflexed, but the apical portion is erect, giving the impression 
of an erect anther. The situation in Huttonaea is not clear. The anther appears to be erect, but there are some indications that it has a slight tendency to being reflexed.

The anther-cells are generally parallel to each other. Huttonaea is exceptional in that the anther cells in these plants diverge toward their bases, while the apices remain proximal to each other. In the Coryciinae, excluding Disperis, the anthercells may still be parallel to each other, but they are far apart, flanking the gynostemium (Fig. 23F). The connective is strap-shaped with the anthercells situated at the ends of the connective. At its apex, the anther is either broadly rounded, emarginate to deeply split, or has a very short obtuse connective process. In species where the antherthecae are separated, the median part of the connective is always rounded or somewhat emarginate. A very prominent connective process, resulting in an acute anther, is found in some Orchideae (especially Serapias) and is considered the ancestral state for the Orchideae and Diseae by Dressler (1990).

Almost all species have prominent lateral gynostemium appendages (Fig. 23). The situation with regard to their derivation from "basal bulges" (staminodes) and "auricles" (filament appendages) is less clear than in the Orchideae (Kurzweil, 1987b), as their primordia are very obscure in the early ontogeny of most Diseae. However, both structures exist in the tribe Diseae and are prominent in certain species.

In Disa obtusa Lindl. the basal bulges are significant during early ontogeny, and later develop into a ridge on the keel connecting the petals with the gynostemium (Kurzweil, 1990). The presence of a similar structure in mature flowers of many Disinae (e.g., Fig. 23E) suggests that this staminodial nature of the keel is the general situation in the subtribe. The auricles develop from signifcant primordia, and in the adult flower are seated on top of the connecting keel and are fused to the latter and to the rostellum. They are very variable in shape, ranging from small and sculptured to large and comparatively flat.

Mature flowers of the Satyriinae have comparatively large lateral gynostemium appendages next to the anther. During the middle and late ontogeny they are distinctly two-lobed, but significant primordia were not observed in the early ontogeny (Kurzweil, in prep.). In some species the bilobed nature persists in the mature flowers. As detailed ontogenetic studies have not yet been made on this genus, it can only be suspected that the two-lobing of the late-ontogenetic appendages indicates their derivation from staminodes and auricles like in most other Orchideae and Diseae.

A keel connecting the petals with the gynostemium is also present in Brownleea (Fig. 23G), and also in this case it may incorporate the staminodes. However, clear ontogenetic evidence was not found in the three species studied (Kurzweil, 1990; Linder \& Kurzweil, in prep.). Huttonaea species have prominent lateral gynostemium appendages, which appear to be derived from auricles only. In the Coryciinae sensu stricto significant lateral gynostemium appendages are never found in mature flowers, and apparently the staminodes are incorporated into the gynostemium tissue below the rostellum (Kurzweil, 1991), while the central thickened portion of the connective may represent fused auricles. Many Disperis species have bi-partite lateral gynostemium appendages (Manning \& Linder, 1992; Kurzweil \& Linder, 1991), with a smooth and erect portion fused to the lip base and a smaller sculptured horizontal portion on the side of the gynostemium. It is possible that the smooth erect portion is a staminodial structure, and that the sculptured horizontal portion represents the auricle.

The primitive condition of the Diseae and Orchideae seems to be the presence of prominent staminodes that are fused to the gynostemium. Since orchids have probably evolved from ancestors with three abaxial and basally fused stamens, the presence of significant lateral staminodes must be regarded as an ancestral feature, and this is apparently the more general state in the orchid family as it is found in most groups (Kurzweil, 1987a, b, 1988; further references are given there). The extensive keels connecting the petals with the gynostemium as found in Brownleea and the Disinae can be regarded as well-developed staminodes and thus as a primitive state, although the formation of the connecting keels is unique and certainly derived. Similar connecting keels are also found in the Brachycorythis group (Orchideae). Comparatively large staminode primordia are found in Disperis fanniniae Harvey and Ceratandra atrata. In the remainder of the Coryciinae, in Huttonaea and possibly in the Satyriinae, the staminodes are strongly reduced, which is clearly derived.

Previously the occurrence of auricles (filament appendages) was regarded as a unique character of the Orchideae and Diseae. However, such structures have also been reported from several groups of the "Diurideae" (Dressler, 1986), although the homology of these structures to the auricles of the Orchideae/Diseae needs more research. Auricles 
TABLE 2. Variation in the structure of the rostellum in the Diseae.

\begin{tabular}{|c|c|c|c|c|c|}
\hline \multirow[b]{2}{*}{ Taxon } & \multicolumn{2}{|c|}{ Number of lobes } & \multirow[b]{2}{*}{ Central lobe } & \multirow[b]{2}{*}{ Lateral lobes } & \multirow[b]{2}{*}{ Viscidium } \\
\hline & mature & primitive & & & \\
\hline Orchideae & 3 & 3 & infrathecal tooth & square to elongate & 2: lateral lobes \\
\hline Disa & 3 & 3 & infrathecal tooth & square & 2: lateral lobes \\
\hline Herschelianthe & 3 & 3 & infrathecal tooth & square & 2: lateral lobes \\
\hline Schizodium & 3 & 3 & infrathecal tooth & square & 2: lateral lobes \\
\hline Monadenia & 1 & 1 & massive & NA & 1: central lobe \\
\hline Brownleea & $2 *$ & $2-3$ & lost or reduced* & elongate, erect & 2: lateral lobes \\
\hline Huttonaea & 3 & 3 & massive & minute & 2: lateral lobes \\
\hline Ceratandra & 2 & 2 & lost & $\begin{array}{l}\text { large, flat, each half cov- } \\
\text { ering one theca }\end{array}$ & 2: lateral lobes \\
\hline Pterygodium & 3 & $1 ?$ & small & elongate, twisted & 2: lateral lobes \\
\hline Corycium & 3 & $2-3$ & small & $\begin{array}{l}\text { moderately elongate, } \\
\text { strongly twisted }\end{array}$ & 2: lateral lobes \\
\hline Disperis & 3 & $2 ?$ & $\begin{array}{l}\text { flat and covering } \\
\text { both thecae }\end{array}$ & elongate, projecting & 2: lateral lobes \\
\hline Satyrium & $1(-3)$ & $1(-3)$ & variable & obscure & 2: lateral lobes \\
\hline Satyridium & 1 & 1 & massive & NA & 1: central lobe \\
\hline Pachites bodkinii & 2 & $?$ & lost & massive & 2: lateral lobes \\
\hline Pachites adpressa & 3 & $?$ & large U-shaped tape & minute & 2: lateral lobes \\
\hline
\end{tabular}

* = exceptions occur; ? = unknown; ( ) = rarely occurring; NA = not applicable.

are certainly the basic condition of the Orchideae and Diseae, and their reduction in the Coryciinae sensu stricto and possibly in the Satyriinae is probably derived.

The rostellum, which is developed from the median carpel apex, as is typical of the orchids, is basically three-lobed. However, the lobes are developed differently in the various groups (Table 2).

In the Disinae the central lobe is folded between the anther cells and varies from relatively small to quite prominent. This is essentially similar to the condition found in many of the Orchideae and may well be the basal condition for the Orchidoideae. Monadenia is unique in the Disinae by its massive central rostellum lobe, with minute or absent lateral lobes.

The situation in the Satyriinae is less clear. Generally, the rostellum is less clearly three-lobed than in the Disinae and the Orchideae. The rostellum is either weakly three-lobed or unlobed although emarginate in some species. In several species there is no evidence of rostellar lobing even in the early ontogenetic stages. Within Satyrium, there is a wide range of different sizes and shapes of the central rostellum lobe (Summerhayes, 1968; Williamson, 1977), ranging from massive and comparatively flat to fingerlike or to short knoblike. The lateral parts bear the viscidia in lateral or subterminal position. A detailed comparative analysis of the diverse rostellum structures may con- tribute valuable characters for a phylogeny of the genus Satyrium, but our data are not at present adequate for wide-ranging interpretations.

The genus Satyridium is characterized by having a median carpel apex/rostellum, which is unlobed throughout the ontogeny and bears a single terminal viscidium in adult flowers. This is an interesting convergence to Monadenia. The two species of the genus Pachites are very different in their rostellum morphology. Pachites appressa Lindl. has a rostellum with small lateral lobes bearing the viscidia and a large U-shaped, straplike central rostellum lobe between them. Pachites bodkinii $\mathrm{H}$. Bol. has a rostellum with two elongate and projecting lateral lobes and an obsolete central lobe. A large structure in the position of a central rostellum lobe was consequently also interpreted as such (Bolus, 1893-1896; Rolfe, 1912-1913; Schlechter, 1901; Schelpe, 1966), but has been shown to contain pollen massulae and thus proves to be a pollen sac (Kurzweil, 1993a).

In Brownleea the rostellum is three-lobed, although the central lobe is usually strongly reduced or subobsolete. This is already visible in the early ontogeny, as the central rostellum lobe is initiated later than the two lateral ones and is insignificant in all stages. This tendency is also present in Huttonaea, in which the rostellum is not deeply threelobed, and the main portion is derived from the central lobe, while the lateral lobes are minute. The 
Coryciinae also show evidence of a successive reduction of the rostellum three-lobing. In Ceratan$d r a$, the rostellum is flat, deeply two-lobed throughout the ontogeny and covers the thecae on their dorsal sides (Kurzweil, 1991). In Corycium and Pterygodium, the anther-thecae are far apart, and the rostellum is then developed as a narrow elongate strap between them. While the main portion of the strap is derived from lateral rostellum lobes, a small but distinct median portion is visible in some species, and this is apparently homologous to a central rostellum lobe. Ontogenetically, the rostellum of Pterygodium and Corycium develops from a shallowly three-lobed, two-lobed, or unlobed median carpel apex. The rostellum of Disperis is very different. The lateral rostellum lobes are developed as elongate projecting arms. The central lobe is remarkable in that it is large and flat and covers the anther. It was shown in one species that the rostellum develops from an initially two-lobed median carpel apex (Kurzweil, 1991), but no ontogenetic information is available from other Disperis species.

The stigma shows some remarkable peculiarities in this tribe. In the Disinae and Satyriinae the stigmatic surface is developed from the three carpel apices, which is the common situation in the Orchidaceae (Fig. 23D, E). The median carpel apex contributes from between half to somewhat less than one-third of the total stigmatic surface, but this is variable even between closely related species. However, in the Coryciinae, as well as in Brownleea (Fig. 23G) and Huttonaea, the stigma is made up entirely of the median carpel apex, and the lateral carpel apices remain as small, sterile, vestigial organs (Kurzweil, 1989, 1991; Kurzweil \& Linder, in prep.). This derivation of the stigma from the median carpel apex is rare in the orchids, and has only been recorded elsewhere in the Spiranthoideae (Rasmussen, 1982). It should be noted that two species in Brownleea, B. parviflora Harvey ex Lindl. and B. mulanjiensis Linder, have stigmas consisting of all three carpel apices. This may either represent a basal condition for the genus, or a secondary reversal. The situation is analyzed in detail in Linder \& Kurzweil (in prep.), and the most parsimonious solution indicates that these two species present a secondary reversal. However, a bootstrap test shows that the alternative solution also gets significant support.

In the Disinae the stigma is distinctly pulvinate and is usually raised on a platform in front of the rest of the gynostemium. In extreme cases the stigmatic surface may have a raised rim along the front margin, so that it faces backwards. Superfi- cially this is similar to the stigma in Satyrium. However, in Satyrium the carpel apices form two lobes, with the adaxial, receptive lobe derived from the fused lateral carpel apices, while the abaxial lobe represents the median carpel apex and is only basally receptive. In Satyridium and Pachites bodkinii, the stigma is a small, slightly convex, round pad on the front side of the gynostemium (= facing the lip). In Pachites adpressa the stigma is a deep cavity encircled by the U-shaped central rostellum lobe, and is developed on the back side of the gynostemium (= facing the median sepal). The stigma of the Disinae and Satyriinae has been called pseudoterminal by Bentham \& Hooker (1883), and Pfitzer (1889) also commented on the often terminal position of the stigma on the gynostemium in the Disinae and Satyriinae.

The Huttonaea/Brownleea/Coryciinae-clade shows a development from the probably primitive entire stigma to two separate stigmas on the rostellum with generally flat to convex receptive area(s). In Huttonaea, the stigma is an entire convex cushion and also develops from a solitary structure (Kurzweil, 1989). In most Brownleea species, the stigma appears to be entire as well but is shallowly grooved in the middle by the adpressed lip. It was found to develop from two separate primordia next to each other (Linder \& Kurzweil, in prep.). In some Disperis species, the appearance of the mature stigma is very similar to that of Brownleea (Kurzweil \& Linder, 1991). In the remainder of Disperis two almost or completely separate stigmas are present. The Coryciinae sensu stricto, with their wide rostellums, have two separate stigmas throughout the ontogeny (Kurzweil, 1991; Kurzweil et al., 1991).

\section{POLLEN SURFACE}

The surface topology and wall anatomy of the pollen surface (Figs. 24-32) provide a substantial set of data, which appear to have great phylogenetic value in the Orchidaceae (Burns-Balogh, 1983; Burns-Balogh \& Funk, 1986). The palynology of the group has been studied by Schill \& Pfeiffer (1977), Linder (1986), Chesselet (1989), and Chesselet \& Linder (1993). The pollen is aggregated into sectile pollinia, which is typical of the subfamily (Lindley, 1830-1840; Burns-Balogh \& Funk, 1986). The tetrads are combined into massulae, and the massulae are united into the pollinium. The massulae are easily separated, and the pollinium does not form a solid body.

The massulae vary extensively in shape. Some 
of this variation may be related to the shape of the flower and the locules, but some appears to be phylogenetically interesting. Chesselet \& Linder (1993) suggest that the massulae are rounded in most of the Disinae, while they are fasciculate in the Coryciinae sensu stricto. Rounded massulae were also observed in the few outgroup taxa studied, and may be the general condition in the Orchidoideae. This variation is largely correlated with the organization of the tetrads. The tetrads are generally tetrahedral in taxa with rounded massulae (Fig. 24), while linear tetrads are found in taxa with fasciculate massulae (Figs. 25, 28). However, while massula shape is easily determined, and relatively constant within samples and genera, the tetrad organization is more difficult to observe and appears to have exceptions. In no pollinia studied was the tetrad organization totally constant, but the frequency of tetrahedral and linear tetrads varied. There are exceptions to the simple pattern described above. Corycium nigrescens Sond., C. dracomontanum Parkman \& Schelpe, and about half of the Disperis species do not have linear tetrads. The two Corycium species were ignored when the genus was coded for cladistic analysis. However, because about half of the Disperis species appear to have the primitive condition, Disperis has been coded for tetrahedral tetrads and nonfasciculate pollinia. A further problem with the character is that tetrad organization has not been widely studied in the subfamily. It is possible that tetrad organization actually causes the massula shape. There is scope for a more detailed, and possibly ontogenetic, investigation of this problem.

The wall structure has some commonalities across the tribe. A foot-layer is always absent, as is typical of the subfamily (Burns-Balogh, 1983). The columellae are always well developed. The wall is semitectate in most of the genera, but the wall is intectate in Disa sect. Micranthae, and it is secondarily tectate in the Coryciinae sensu stricto (Corycium, Ceratandra, Evotella, and Pterygodium). Although Burns-Balogh (1983) suggested that the Orchidoideae are primitively intectate, Chesselet \& Linder (1993) propose that the semi- tectate condition is primitive in the Diseae. This is corroborated by the analyses here.

Pollen-surface ornamentation provides a wealth of useful data. The surface ornamentation is baculate in Disa sect. Micranthae, but is actually produced by the columellae, and is therefore not homologous with an ornamentation produced by the tectum. The walls are tectate in the Coryciinae sensu stricto, and the ornamentation consists of striations on the tectum. The remainder of the Diseae have semi-tectate walls which are either reticulate (Fig. 29) or have a more or less rugose or hamulate ornamentation (Figs. 30, 31). The Disinae generally have a rugose or hamulate ornamentation (Fig. 27). The situation in Satyrium is still confused, with an initial wide survey revealing extensive variation ranging from reticulate to hamulate ornamentation (Fig. 32). Hamulate ornamentation has also been recorded in two species of Corycium (C. dracomontana and C. nigrescens), while the rest of the Coryciinae have reticulate ornamentation. This suggests that a reticulate ornamentation may be the primitive condition in the Diseae, and that the hamulate condition may be treated as a synapomorphy for the Disinae. As the occurrence of hamulate pollen ornamentation is rare outside the Disinae, its occurrence was ignored when the genera were coded for the cladistic analysis.

\section{SEEDS}

The seeds are very uniform in the Diseae (Figs. 33-44, Kurzweil et al., 1991; Kurzweil, 1993b), and apparently do not carry much taxonomically useful information. The seeds of the Diseae are almost always minute and of the same structure as in the related tribe Orchideae (Healey et al., 1980; Barthlott, 1976; Ziegler, 1981; Tohda, 1983; Wildhaber, 1972; unpublished data). The seeds are usually fusiform in general shape as in most other orchids, although cylindrical and globose seeds occur occasionally (Fig. 39). The seedcoat consists of dead cells with their outer periclinal walls concave and adpressed to the inner one. The

Figures 24-32. SEM micrographs of pollen ultrastructures. Scale bars: $50 \mu \mathrm{m}$ in $24-26,5 \mu \mathrm{m}$ in $27-32$. 2426. Massulae.-24. Disa pulchra Sond., with tetrahedral tetrads. - 25. Pterygodium alatum (Thunb.). Sw., with elongated tetrads. - 26. Satyrium erectum Lindl. 27-32. Surface ornamentation. - 27. Disa pulchra Sond.; note the hamulate ornamentation.-28. Pterygodium catholicum (L.) Sw.; note the fasciculate massulae and linear tetrads. - 29. Disperis capensis Sw., with a reticulate tectum. - 30. Satyrium sphaerocarpum Lindl., with a finely rugose surface. -31 . S. erectum Lindl., with a rugose surface.-32. S. striatum Thunb., with a hamulate surface. Sources (HK = H. Kurzweil). 24: HK 1253, 25: HK 949, 26: HK 1508, 27: HK 1253, 28: HK 1543, 29: HK 1503, 30: HK 1424, 31: HK 1508, 32: HK 1369. 

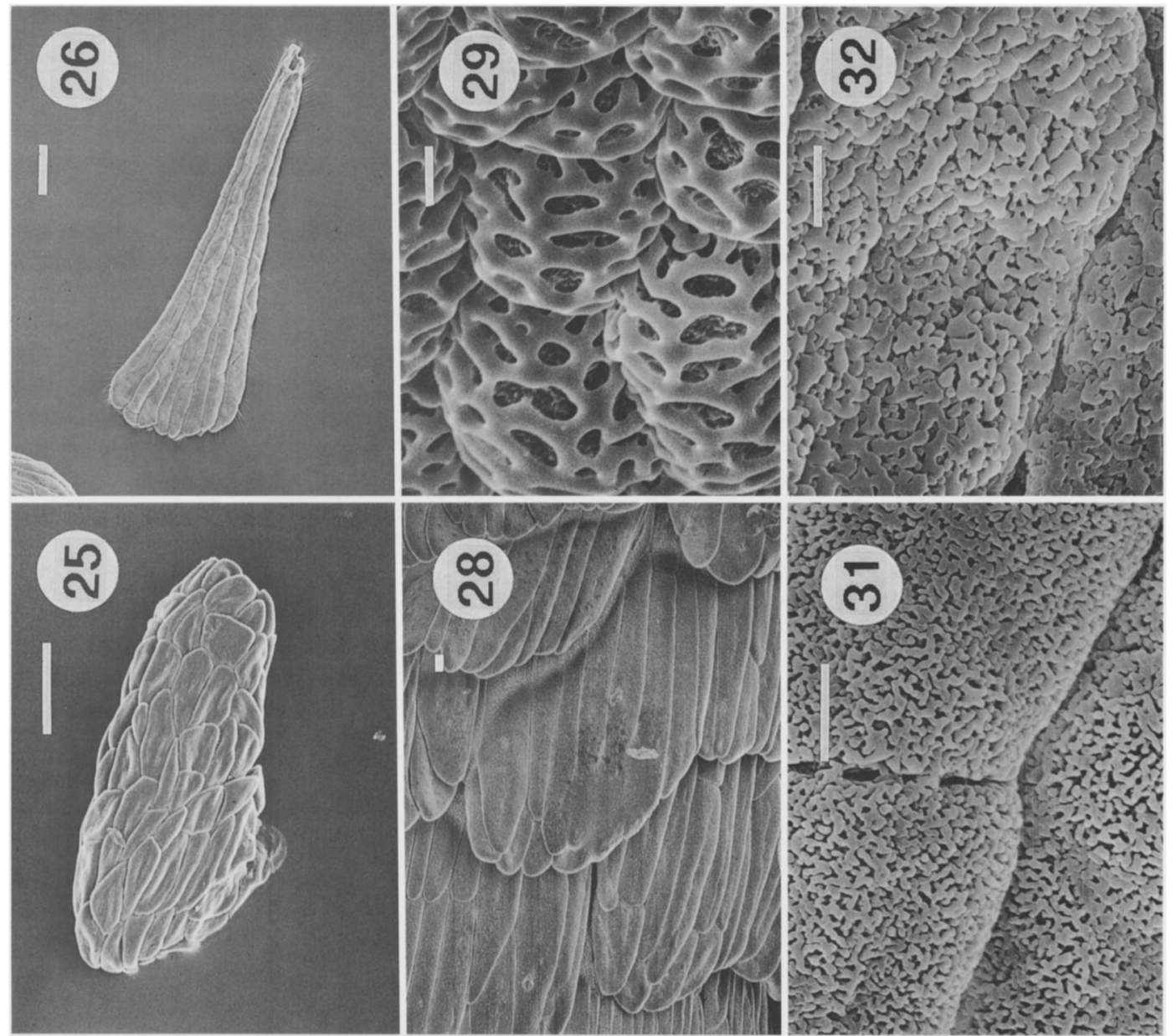

(2)
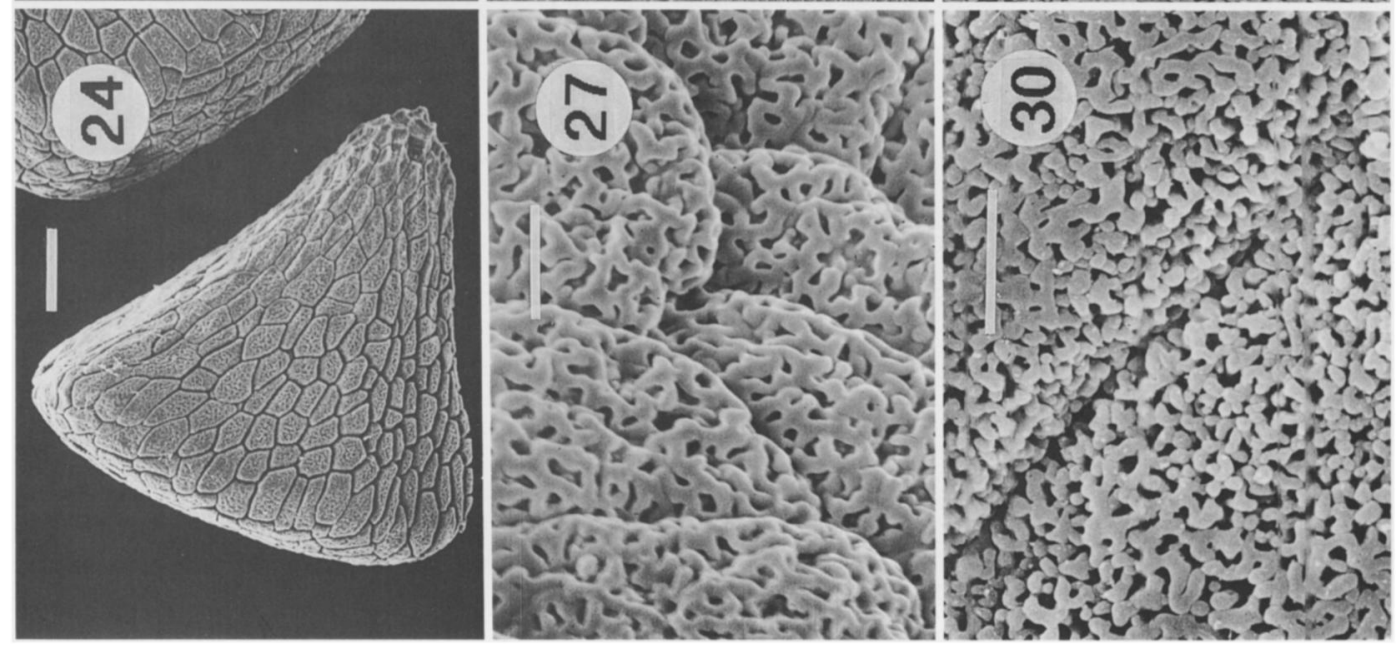

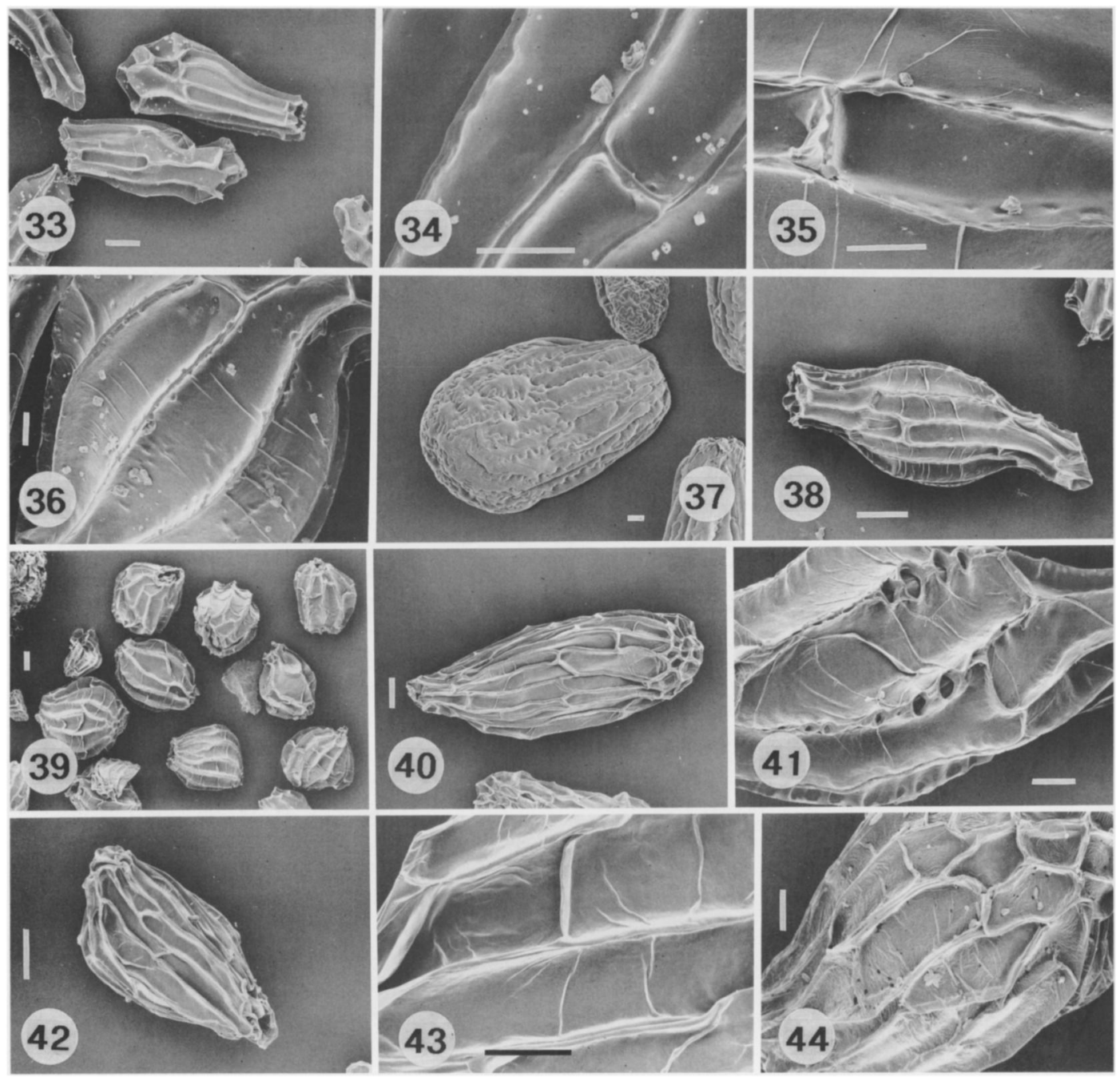

Figures 33-44. SEM micrographs of seeds and seed surfaces. Scale bars: $50 \mu \mathrm{m}$ in $33,37-40,42 ; 20 \mu \mathrm{m}$ in 34-36, 41, 43, 44.-33, 34. Disa chrysostachya Sw., with almost cylindrical seed and irregularly thickened anticlinal walls. -35 . D. caffra $\mathrm{H}$. Bolus; note the concavities in the marginal part of the periclinal walls. $-36 . D$. cornuta (L.) Sw., with irregularly thickened walls. - 37. D. tripetaloides (L.f.) N.E. Br.; note the large swollen seed. 38. Monadenia bracteata (Sw.) T. Durand and Schinz, with a typical fusiform seed. - 39. M. comosa Rchb. f., with a globose seed.-40. Brownleea macroceras Sond., fusiform seed with comparatively thick anticlinal walls. - 4l. Disperis renibractea Schltr.; note the prominent holes between the anticlinal walls of adjacent cells. $-42,43$. Satyrium stenopetalum Lindl. subsp. stenopetalum. - 44. Pachites bodkinii H. Bolus, showing finely sculptured periclinal walls. Sources. 33, 34: Levyns 10827, 35: McLoughlin 521, 36: Linder 3070, 37: Compton 12809, 38: Kurzweil 1384, 39: Fourcade 5064, 40: Bockelmann s.n., 41: Schelpe 5258, 42, 43: Schelpe 5794, 44: Vlok 62.

cells in the median portion of the seed are elongate, considerably larger, and also more regular in shape than the cells at both ends of the seed. The anticlinal walls are raised and are fused to the anticlinal wall of the adjacent cell. The fusion is usually not complete, and a groove indicates the derivation of the resulting "ridge" from two different anticlinal walls (especially at the corners of the cells). Prominent holes are visible between the anticlinal walls of adjacent cells (Fig. 41 ) in the Disperis species studied. The anticlinal walls may be somewhat enlarged and slightly projecting from the seed surface, but prominent hooks as in many vandoid orchids (Chase \& Pippen, 1988) were not observed. They may also be variously irregularly thickened ("beaded" sensu Clifford \& Smith, 1969). The anticlinal walls are straight or slightly wavy in the majority of species, but seeds with strongly undulating an- 
TABLE 3. Character list for the Diseae. All multistate characters were coded as nonadditive characters.

1. Cauline leaves: all same size (0), grading from large at the base to small at the apex (1).

2. Sepals brightly colored (0), green (1).

3. Sepals often apiculate (0), almost never (1).

4. Dorsal sepal similar to the lateral sepals (0), dorsal sepals galeate (1).

5. Dorsal sepal ecalcarate (0), spurred (1).

6. Petals similar to the lateral sepals (0), different (1).

7. Petals fused to gynostemium (0), free (1).

8. Petals adnate to dorsal sepal (0), free (1).

9. Strongly developed petal nerves absent (0), petal nerves frequently present (1).

10. Lip fused to base of gynostemium (0), free (1).

11. Lip with a fundamentally bilobed appendage (0), not (1).

12. Lip with two spurs (0), unspurred (1), with one spur (2)

13. Lip galeate (0), not (1).

14. Lip erect at the base (0), patent or descending at the base (1).

15. Lip appendage bilobed (0), single and fused (1).

16. Lip blade simple (0), spathulate and anchor-shaped (1).

17. Column-part well developed (0), not and very short (1).

18. Lateral gynostemium appendages well developed (0), small to absent (1).

19. Anther erect (0), reflexed (1).

20. Anther cells adjacent (0), widely separated by a wide connective (1).

21. Pollen tetrads tetrahedral (0), elongated (1).

22. Massulae rounded (0), massulae fasciculate (1).

23. Pollen surface sculpturing reticulate $(0)$, rugose or hamulate (1), striate (2).

24. Pollen surface semi-tectate $(0)$, secondarily tectate (1).

25. Rostellum three-lobed (0), only the central lobe developed (1).

26. Rostellum central lobe an intrathecal tooth $(0)$, reduced or small to lost ( 1 ), flat and covering both theca (2), massive and making up the whole rostellum (3), massive between small lateral rostellum lobes (4).

27. Rostellum lateral lobes square to elongate-erect $(0)$, minute (1), elongate-spreading (2).

28. Rostellum with elongated spreading lateral lobes which are flat and expanded (0), projecting (1), twisted (2).

29. Stigma sessile on the gynostemium (0), subterminal (1).

30. Stigma produced from all three carpels (0), median only (1).

31. Median carpel stigmatic part from one primordium (0), two primordia (1).

ticlinal walls were found in Ceratandra, Corycium carnosum (Lindl.) Rolfe (Kurzweil et al., 1991), and in Satyrium retusum Lindl. (Kurzweil, 1993b). The surface of the periclinal cells is variously smooth to more or less wavy; however, the prominent ornamentation found in several Orchideae (Barthlott, 1976; Healey et al., 1980; Tohda, 1983) was not observed here. The marginal parts of the periclinal cells have occasionally small shallow concavities (Fig. 35, observed in five species). Periclinal ridges are well developed as in the Orchideae, but their intervals as well as their thickness and number are too variable to give any phylogenetic information.

A remarkably different seed type was found in Disa tripetaloides (L.f.) N.E. Br., D. uniflora, D. cardinalis Linder, and D. caulescens Lindl., which have considerably larger seeds and numerous surface cells with slightly convex periclinal walls (Fig. 37, Kurzweil, 1993b).

\section{Cladistic Analysis}

The characters that were found to be cladistically informative are listed in Table 3 , and their distribution among the taxa is given in Table 4 .

The cladistic analysis located three trees with a length of 57 steps, a consistency index of 66, and a retention index of 85 . Two of the three trees show different topologies for the basal node of the Diseae (Fig. 45A, B), while the third tree is a more resolved topology of the second tree, and the consensus tree shows a basal polychotomy for the subtribes (Fig. 45C). The successive weighting had to be run twice before the cladogram stabilized. Two trees were located, which differed only in the arrangement of the three outgroup taxa. This is the basic topology presented in Figures 46 and 47 , on which the subsequent discussion is based. The supporting characters for the cladogram are given in Figure 46, and the node numbers and "bootstrap percentiles" are indicated in Figure 47.

\section{SYSTEMATIC INTERPRETATION}

DISEAE

Dressler's (1981) concept of a single tribe, the Diseae, to combine the groups with reflexed anthers, is supported (contrary to Szlachetko, 1991), and this group is retrieved at node 13 . This node is supported by a single character (reflexed anther, character 19) which reverses for one group (Disa sect. Micranthae). Dressler (1981) also based his recognition of the Diseae on this character, and Burns-Balogh \& Funk (1986) noted that the Disinae and Satyriinae both have bent gynostemium apices, which may refer to the same condition. The node has a "bootstrap percentile" of 62 , but this analysis does not present a rigorous testing of the hypothesis of monophyly for the Diseae, as only 
TABLE 4. Distribution of characters among the taxa. Disa refers to the genus Disa excluding section Micranthae, while Micranthae refers to Disa sect. Micranthae. Missing or variable characters, or logically inapplicable characters are coded as "?."

\begin{tabular}{llllllll}
\hline \hline Brachycorythis & 11100 & 10111 & 12100 & 01000 & 00000 & $00 ? 00$ & 0 \\
Holothrix & 11100 & 11101 & 12100 & 01100 & 00000 & $00 ? 00$ & 0 \\
Schizochilus & 11100 & 11101 & 12100 & 01000 & 00000 & $00 ? 00$ & 0 \\
Satyrium & 10100 & $011 ? 1$ & 10000 & $00 ? 10$ & 00000 & $? 1 ? 10$ & 0 \\
Pachites bodkinii & 10100 & 01111 & 11100 & 00010 & 00000 & $10 ? 10$ & 0 \\
Pachites adpressa & 10100 & 01111 & 11100 & $00 ? 10$ & 00000 & $41 ? 10$ & 0 \\
Satyridium & 10100 & 01111 & 10000 & 00110 & 00001 & $3 ? ? 10$ & 0 \\
Disa & 10011 & 10101 & 11110 & 01010 & 00100 & $00 ? 10$ & 0 \\
Herschelianthe & 10011 & 10101 & 11110 & 01010 & 00100 & $00 ? 10$ & 0 \\
Micranthae & 10011 & 10101 & 11110 & 01000 & 00100 & $00 ? 10$ & 0 \\
Monadenia & 10011 & 10101 & 11110 & 01010 & 00101 & $31 ? 10$ & 0 \\
Schizodium & 10011 & 10101 & 11100 & 01010 & 00100 & $00 ? 10$ & 0 \\
Brownleea & 10111 & 10010 & 11100 & 01010 & 00000 & $10 ? 01$ & 1 \\
Huttonaea & 11100 & 11101 & 11110 & 01010 & 10000 & $41 ? 01$ & 0 \\
Disperis & $1 ? 1 ? ?$ & 11010 & 01100 & 01010 & 00000 & 22101 & 1 \\
Corycium & 11100 & 11010 & 01101 & 01111 & 11210 & 12201 & 1 \\
Ceratandra & 01100 & 11010 & 01100 & 11111 & 11210 & 12001 & 1 \\
Evotella & 01100 & 11010 & 01100 & 11111 & 11210 & 12001 & 1 \\
Pterygodium & 11100 & 11010 & 01101 & 01111 & 11210 & 12201 & 1 \\
\hline
\end{tabular}

three genera of the Orchideae were used in the outgroup. One of these genera, Brachycorythis, has several characters in common with some members of the Diseae, and this probably accounts for the relatively low "bootstrap percentile" for this node. It would be necessary to analyze the whole subfamily Orchidoideae in order to substantiate the monophyly of the Diseae-such a global analysis is long overdue.

Two clades are recognized in the Diseae. The first clade (node 10) includes the Satyriinae and the Disinae, excluding Brownleea. The second clade (node 12) includes the Coryciinae, as well as Huttonaea and Brownleea.

In two of the three fundamental trees, the Satyriinae are combined with the Disinae at node 10 (Fig. 46). The characters supporting this arrangement are the subterminal stigma (character 29) and the brightly colored sepals (character 2). The former character was also used by Bentham \& Hooker (1883) and Pfitzer (1889) to diagnose this group, while Rolfe (1912-1913) separated his Diseae from the Corycieae by the lip not being fused to the gynostemium (thus implying that the Diseae sensu Rolfe is paraphyletic, as the Diseae are then based on the absence of a character). Neither character is very good. A subterminal stigma is difficult to define clearly and may also occur in the Coryciinae, where the floral structure is too contorted to make such fine distinctions. Brightly colored sepals also occur sporadically in other groups. Schlechter (1901), who also recognized this group, criticized the characters used by Bentham \& Hook- er (1883) and Pfitzer (1889), and suggested that a raised and sharply delineated stigma, as well as a tall rostellum, may better define the group. However, both these characters occur in modified form in the Coryciinae. It is therefore evident that, although the group has been frequently recognized in the past, it lacks convincing empirical support. The "bootstrap percentile" for this node is only 13 , thus indicating that there is little support for the combination of the Disinae and the Satyriinae, as suggested by Bentham \& Hooker (1883), Pfitzer (1889), Schlechter (1901), and Rolfe (1912-1913).

This very low percentile may be affected by the interpretation of the evolutionary origin of Brownleea. Brownleea is placed in the Coryciinae clade in the tree located by successive weighting, as compared to its previous position in the Disinae. An inspection of the character distributions shows that it has many of the characteristic features of both the Disinae and the Coryciinae. These may have evolved in parallel in Brownleea and the Disinae, as a result of a similar pollination syndrome, compared with the oil-collecting bee syndrome that appears to be central to the evolution of the coryciinoid flower structure. This might account for the spurred dorsal sepal and the brightly colored tepals, with the fusion between the petals and the gynostemium providing mechanical strength for directing the pollinator into the spur of the dorsal sepal.

An alternative hypothesis could be that Brownleea originated as a hybrid between the Coryciinae and the Disinae. The cladistic results were inves- 


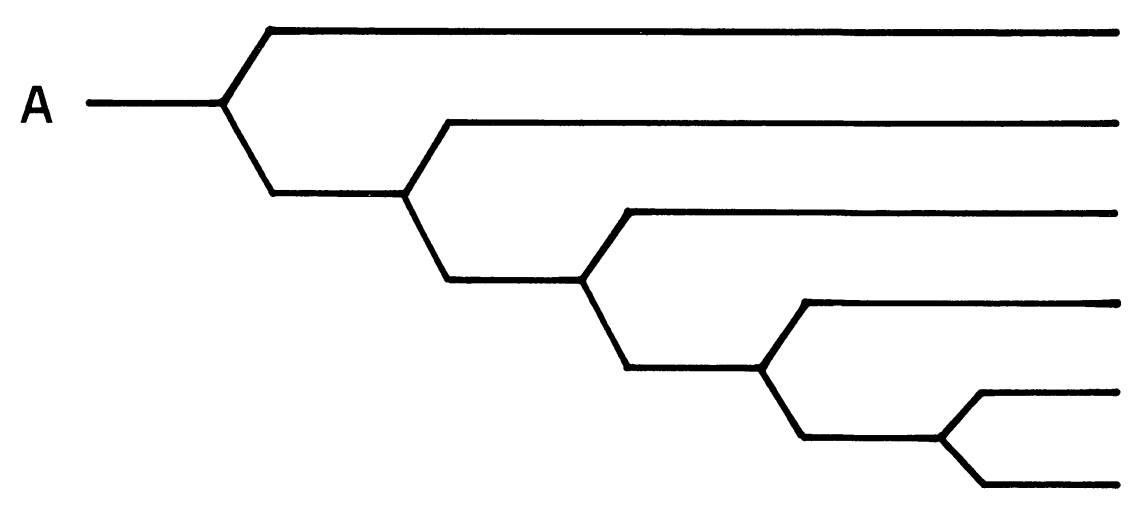

OUTGROUP

HUTTONAEA

DISINAE

SATYRIINAE

BROWNLEEA

CORYCIINAE

B

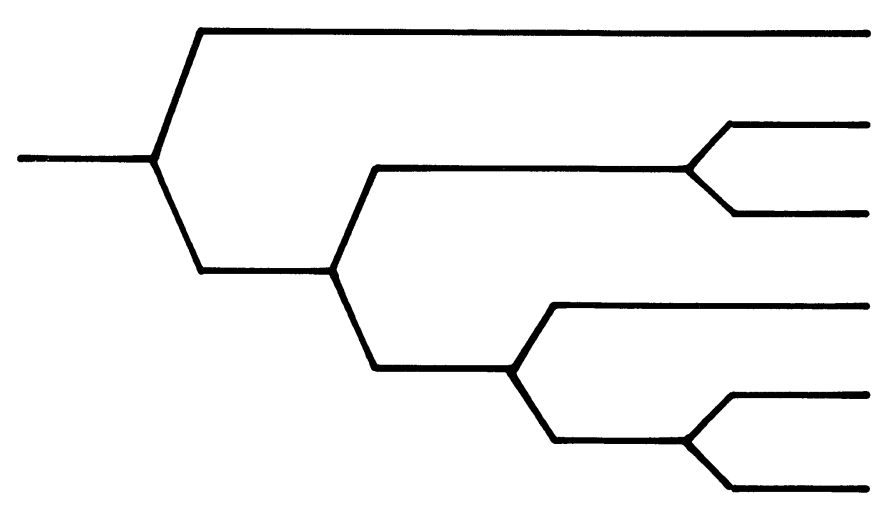

OUTGROUP

SATYRIINAE

DISINAE

HUTTONAEA

BROWNLEEA

CORYCIINAE

C

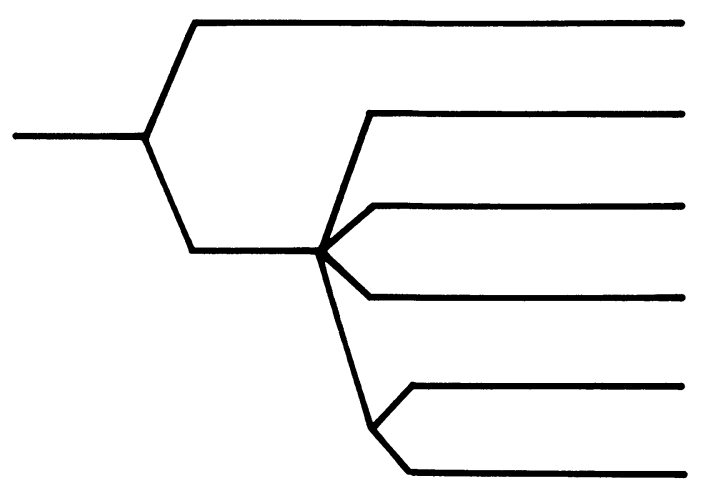

OUTGROUP

HUTTONAEA

DISINAE

SATYRIINAE

BROWNLEEA

CORYCIINAE

FIGURE 45. The basic structure of the trees retrieved in the analysis. - A. Fundamental tree 1.-B. Fundamental tree 2. - C. Strict consensus tree of the three fundamental trees. The outgroup is as defined in the text.

tigated for patterns that might corroborate such a hybrid origin. Funk (1985a) suggested seven criteria by which hybrids can be recognized cladistically.

(1) "When there are two cladograms of similar length and one taxon position changes, the taxon that is moving may be a hybrid and the two taxa between which it is moving may be the parents." This pattern was not observed in this study. In the three equal length trees the components below the 


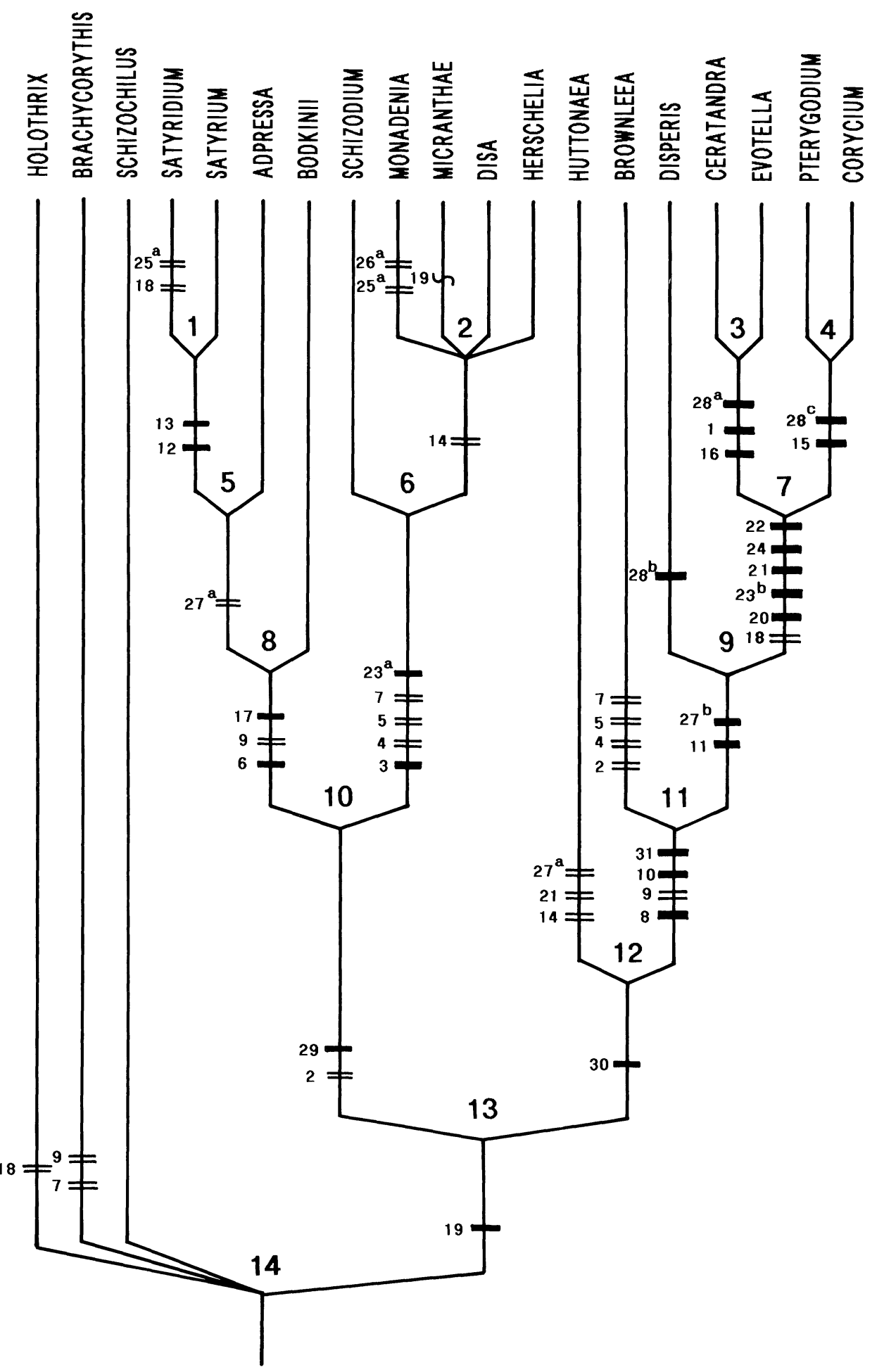

FIGURE 46. One of the two shortest cladograms of the tribe, showing the distribution of the characters numbered according to Table 2 . Solid bars indicate unique synapomorphies; parallel lines indicate characters that evolved several times and wavy lines indicate reversals. The larger numbers at the nodes indicate the node numbers referred to in the text. 


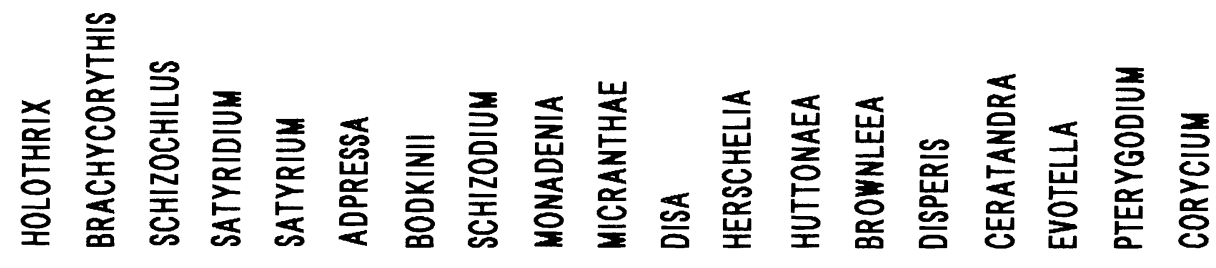

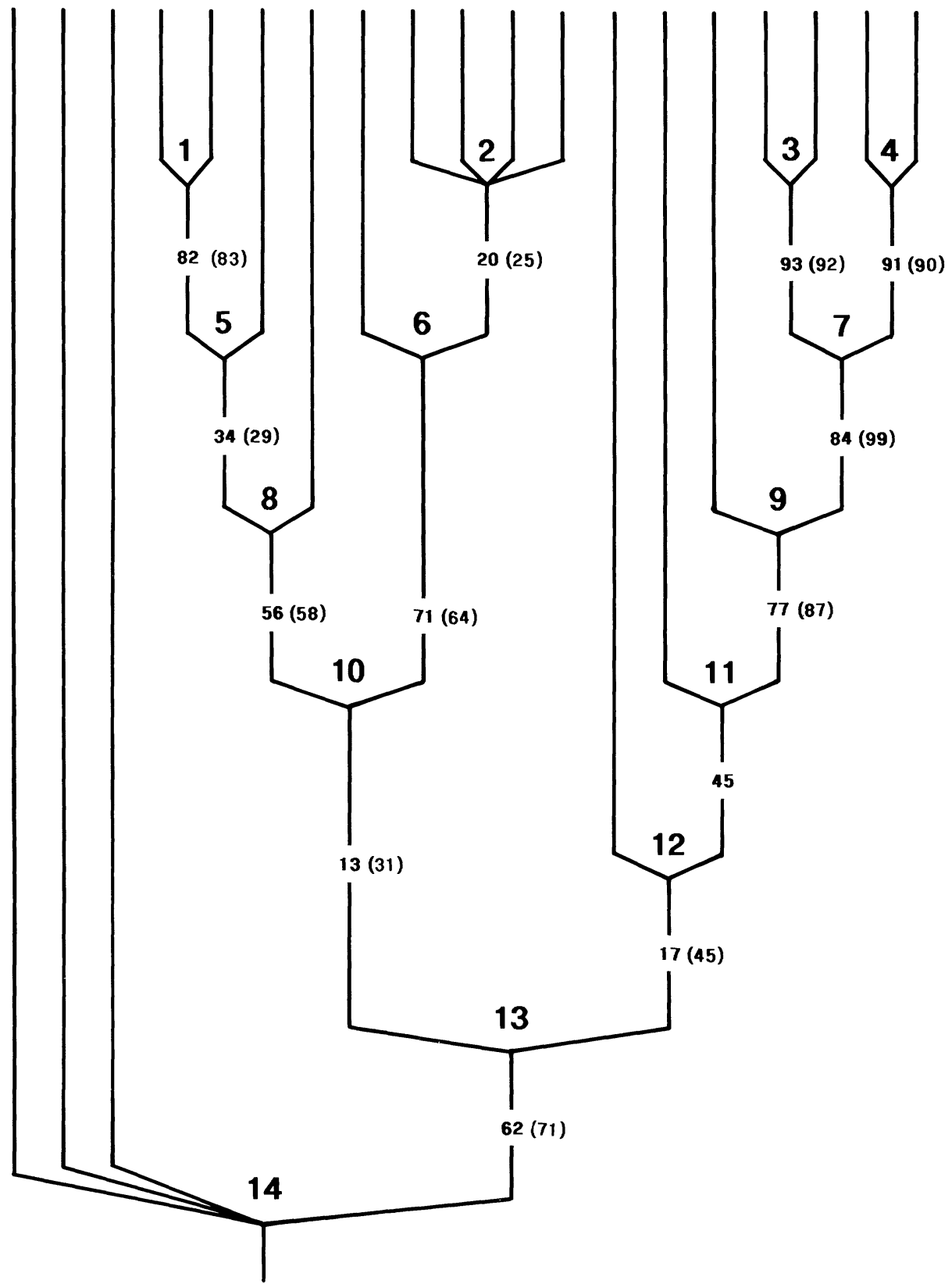

FIGURE 47. Cladogram given in Figure 46, with the bootstrap confidence percentiles indicated at each node, and the percentiles calculated with Brownleea excluded from the analysis given in brackets. The nodes are numbered as in Figure 46. 
hybrid are variously arranged, but Brownleea is always associated with the Coryciinae.

(2) ". . . it is possible to follow a path of character conflicts." Thus there should be a set of character conflicts, showing that the hybrid contains the synapomorphies of the two parental lineages. This is evident in this case, as Brownleea has virtually all autapomorphies of the Coryciinae as well as those of the Disinae. The coryciinoid characters are the petals adnate to the dorsal sepal (8), a lip that is fused to the gynostemium (10), a stigma produced only from the median carpel (but see the discussion of this character above) (30), as well as the stigmatic part of the median carpel developing from two primordia (31). The disinoid characters are the galeate and spurred dorsal sepal $(4,5)$ and the petals which are fused to the gynostemium (7). By moving Brownleea from one clade to the other, the clade without Brownleea is virtually rendered paraphyletic, which it would of course be if Brownleea is of hybrid origin.

(3) "Taxa that are defined solely by character conflicts may be hybrids or parents." This applies, in the tree in Figure 46, to the Disinae, which are here postulated as one parent. If Brownleea were to be included in the Disinae, the Coryciinae would be defined by seven characters, of which five are conflicting. This would identify the Coryciinae as the other parent.

(4) "Taxa with reversals may be hybrids." Brownleea shows no reversals.

(5) "Taxa without autapomorphies may be parents." This is effectively the same as (3).

$(6,7)$ The lack of consensus on a strict consensus tree may be traced to a hybrid taxon. This is indeed what is found here; with three equal length trees the consensus gives a basal polychotomy (Fig. 45C). To test whether Brownleea is causing the collapse of the cladogram, this taxon was removed from the data-matrix. The analysis without Brownleea produced a single most parsimonious tree, identical to the tree retrieved by successive weighting (Figs. 46, 47), with a consistency index of 73 (compared to 67 for the analysis including Brownleea), thus clearly demonstrating that the problem lies with Brownleea.

A further criterion for hybrid recognition can be introduced. If the hybrid is removed from the data-matrix, and a bootstrap analysis is re-run, the nodes below the parents of the hybrid should have a higher percentile support. This was found here, with the nodes below the Disinae increasing from $13 \%$ to $31 \%$, and below Huttonaea from $17 \%$ to $45 \%$ (Fig. 47).
Phipps et al. (1991) in an analysis of the Maloideae (Rosaceae), which are also of putative hybrid origin, suggest that complex character incongruence within the maloids might have been the result of polychotomous early evolution within the clade, caused by the hybrid origin. Within Brownleea there are also reversals in quite "fundamental" characters and unusual character combinations (Linder \& Kurzweil, in prep.), which might also indicate early polychotomous evolution caused by a hybrid origin.

Although hybrid species have frequently been demonstrated cladistically (Funk, 1982, 1985a; Humphries, 1981; Wagner et al., 1985), there have been relatively few such demonstrations at higher taxonomic levels (e.g., the Maloideae, Phipps et al., 1991).

\section{SATYRIINAE}

The Satyriinae, including Pachites, Satyridium, and Satyrium, form a rather weakly supported group, with only three synapomorphies and a "bootstrap percentile" of 56 (see Fig. 47, node 8). The most important character combining the taxa in this group is the elongated column-part, which is unique in the Orchidoideae (character 17). A second synapomorphy for this group is the lack of differentiation between the petals and the sepals, but this may well be a plesiomorphic condition, as it is the ancestral orchidaceous condition. Dressler (1981) suggested that the lack of resupination may also be used as a character, but this recurs frequently in the Diseae and cannot be given much emphasis. The two species of Pachites do not group together, indicating that they do not form a monophyletic group, and that the genus should be subdivided. Although the two species share the same general appearance, this is largely due to symplesiomorphic characters, and they have very different gynostemium structures. Both species of Pachites are lacking in derived features, making their placement anywhere complicated, and lowering the "bootstrap percentiles" linking them in anywhere. As the one peculiar feature they share is the elongated column-part, they are probably best kept in the Satyriinae.

\section{DISINAE}

The Disinae, even with the removal of Brownleea, form a moderately supported group, as indicated by node 6 (Fig. 47). This node is supported by two unique characters, and by three characters shared with Brownleea, and has a "bootstrap per- 
centile" of 71 . Neither of the two unique synapomorphies for the group is very convincing. Character 3 , the presence of apiculate sepals, may be the retention of an ancient monocotyledonous character that occurs widespread in the subclass (see Weber, 1980). Character 23, a rugose or hamulate pollen surface, also occurs sporadically in other groups in the Orchidoideae. The other characters $(4,5,7)$ are linked to a pollination system shared with Brownleea: brightly colored sepals, a spurred dorsal sepal, and the petals fused to the base of the gynostemium. With Brownleea included, the subtribe would be much better supported - this is discussed above. The included taxa show a great deal of phenetic similarity, thus bedeviling the generic classification, and confounding any attempt up until now to delimit monophyletic genera in it. In addition, Disa is most probably not monophyletic. This is indicated by the lack of resolution within the clade.

\section{CORYCIINAE}

The Coryciinae form a clearly monophyletic group, but the critical issue is the delimitation of the subtribe. The Coryciinae sensu stricto (Kurzweil et al., 1991), including the genera Evotella, Ceratandra, Corycium, and Pterygodium (Fig. 47, node 7) are very well supported by five unique synapomorphies and one parallel character, and consequently it is not surprising that it has a "bootstrap percentile" of 84. If Disperis is included (the classical delimitation of the Coryciinae, followed by all previous authors), then only two characters are synapomorphic for the group, but the "bootstrap percentile" is still relatively high at 77 . This lower level of support suggests that the Coryciinae could be delimited excluding Disperis. If Disperis were to be excluded from the Coryciinae, it would have to be placed in its own subtribe. However, a subtribe containing a single genus does not carry any information, and the information that Disperis is the sister taxon to the Coryciinae sensu stricto can be presented by the sequencing conventions of Wiley (1981). On balance, it would appear to be more informative to include Disperis in the Coryciinae.

\section{BROWNLEEA}

The phylogenetic position of Brownleea could be indicated by sequencing criteria, thus obviating the need for a special subtribe for the genus. However, from the bootstrap analysis it is evident that there is rather ambiguous support for a clade including Brownleea and the Coryciinae, and there- fore this would be a poor node at which to establish a formal taxon (Linder, 1991), as further information may result in a change in that portion of the cladogram. Formal taxa should be established at nodes with a high "bootstrap percentile," because these are more robust, and thus less sensitive to new data.

In addition, as was argued above, there is a strong possibility that Brownleea may have originated as a hybrid between the Coryciinae and the Disinae. If Brownleea were of hybrid origin, then Brownleea plus the Coryciinae would not be a monophyletic taxon, as it would include genetic material from two distinct ancestors. As monophyly is the single most important criterion for a taxon (Wiley, 1981; Funk, 1985b), this would argue strongly against including Brownleea in the Coryciinae. Hybrid taxa are polyphyletic, and the best approach may be to define them as narrowly as possible, and to give them the same rank as their parents.

Placing Brownleea in a distinct subtribe from the Coryciinae would emphasize the very real differences between the two groups. With Brownleea excluded, the Coryciinae form a relatively uniform taxon, with a relatively uniform pollination syndrome, and may similar structures. The group is biologically homogenous. With Brownleea included, the group becomes biologically more diverse, and predictions or general biological statements about the group are greatly reduced. Classifications should be "maximally informative" (Wiley, 1981) or as Stevens (1985) noted, limits of genera (or all taxa) can be adjusted to serve many purposes, including that they be separated by a clear morphological gap.

We therefore argue that because the "bootstrap percentile" is relatively low, Brownleea is biologically rather different from the Coryciinae, and the possibility that it may be of hybrid origin cannot be discounted; it would be most informative to place it in its own subtribe.

\section{HUTTONAEA}

If Brownleea is placed in its own subtribe, then it follows that Huttoneae must also be recognized, at least at the subtribal level, in order to maintain the monophyly criterion.

However, the situation does change if the hypothesis that Brownleea is a hybrid could be corroborated. It would no longer be logically incorrect to include Huttonaea in the Coryciinae, because it would be the sister group to the Coryciinae as 
presently circumscribed. There is little character support for including Huttonaea in the Coryciinae. Even with Brownleea excluded from the analysis, the "bootstrap percentile" is a low 45 and there is only a single character supporting the node. However, this character (a stigma derived solely from the median carpel apex) can be regarded as a "fundamental" character that is well understood both ontogenetically and in terms of its taxonomic distribution.

As with Brownleea, two arguments could be advanced against including Huttonaea in the Coryciinae. First, Huttonaea is morphologically very peculiar and has been placed in its own subtribe by both Senghas (1973-1974) and Dressler (1981). The pollination biology is not known, but the gynostemium shows little general resemblance to the Coryciinae, and the perianth is very different. This great degree of dissimilarity would be lost if they were to be included in the same subtribe. Second, the "bootstrap percentile" for the node, even with Brownleea excluded, is a low 45, reflecting the fact that at present a single synapomorphy is known for the group. This implies that the node would be very susceptible to new data. As Huttonaea is at present in its own subtribe, it would be conservative to retain this situation until more information is available, and more robust solutions can be found.

\section{Formal Classification}

\section{Tribe ORCHIDEAE.}

Lip usually spurred, anther erect. This tribe includes about 1700 species (Dressler, 1981).

Tribe DISEAE Dressler, Selbyana 5: 204. 1979.

Anther reflexed, lip spurless or with two spurs. Includes ca. 420 species, largely African with a few species reaching the Far East. Subtribe SATYRIINAE Schlechter, Notizbl. Bot. Gart. Berlin-Dahlem 9: 568. 1926. Satyrieae (Schlechter) Szlach., Folia Geobot. Phytotax. 26: 326. 1991.

Petals similar to the lateral sepals, column-part elongated. Ca. 106 species.

Pachites Lindl., Gen. Sp. Orch.: 301. 1835.

This includes two species (Stewart et al., 1982), but as noted above the genus is probably not monophyletic.

Satyridium Lindl., Gen. Sp. Orch.: 345. 1838.

Monotypic (Linder, 1989).

Satyrium Swartz in Kong. Vet. Akad. Handk. 21: 214. 1800 .

This genus has not yet been revised over its whole distribution range, and estimates of the number of species range from ca. 100 to 117 (Summerhayes, 1968; Hall, 1982; Linder, 1989).

Subtribe DISINAE Bentham, Gen. Pl. 3: 464. 1883.

Dorsal sepal spurred; petals adnate to the gynostemium; sepals apiculate; pollen surface rugose or hamulate. 168 species. Schizodium Lindl., Gen. Sp. Orch.: 358. 1838.

Six species (Linder, 1981b).

Disa Bergius, Descrip. Pl. Cap.: 348. 1767. 128 species (Linder, 1981c, f).

Herschelianthe Rauschert, Feddes Repert. 94: 434. 1983.

The correct name of this genus is at present problematic. Rauschert (1983) suggested that the name it was originally known under, Herschelia Lindl., is a homonym for Herschellia Reichb.f., and proposed the new name Herschelianthe. The oldest name available is Forficaria Lindl. Either Herschelia Lindl. should be conserved, or Forficaria should be applied. As this group of "blue disas" are well known under Herschelianthe, we are using this name here, while recognizing that it is not nomenclaturally the correct name. 18 species (Linder, 1981e).

Monadenia Lindl., Gen. Sp. Orch.: 356. 1838. 16 species (Linder, 1981d).

Subtribe BROWNLEEINAE Linder \& Kurzweil, subtribe nov. TYPE: Brownleea Harv. ex Lindl.

A Disinis labio erecto, petalis sepalo dorsali connatis, a Corycïnis petalis gynostemio connatis recedit.

Lip erect, reduced and fused to the base of the gynostemium; the petals adnate to the dorsal sepal and fused to the gynostemium.

Brownleea Harv. ex Lindl. in Hook. Lond. J. Bot. 1: 16. 1842.

Includes seven species (Linder, 1981a, 1985).

Subtribe HUTTONAEINAE Schlechter, Notizbl. Bot. Gart. Berlin-Dahlem 9: 568. 1926. Huttonaeae (Schlechter) Szlach., Folia Geobot. Phytotax. 26: 326. 1991.

Stigma derived only from the median carpel apex; anthers diverging; petals clawed and fimbriate.

Huttonaea Harv., Thes. Cap. 2: 1. 1863.

Five species (Stewart et al., 1982). 
Subtribe CORYCIINAE Bentham, Gen. Pl. 3: 464. 1883. Corycieae (Bentham) Szlach., Folia Geobot. Phytotax. 26: 326. 1991. Disperidinae Schlechter, Bull. Herb. Boiss. 6: 800. 1898.

Stigma derived only from the median carpel apex; lip with an appendage and fused basally to the gynostemium. Ca. 134 species.

Disperis Swartz, Kongl. Vet. Akad. Handl. 21: 218. 1800 .

This is a wide-ranging genus, reaching from southern Africa to New Guinea, and the precise number of species is not known. The current estimates are ca. 84 (Verdcourt, 1968; Manning, pers. comm.).
Ceratandra Ecklon ex Bauer, Ill. Orch. Plants 4. t. 16. 1827.

Six species (Kurzweil et al., 1991).

Evotella Kurzweil \& Linder, Pl. Syst. Evol. 175: 215. 1991.

Monotypic.

Pterygodium Swartz, Kongl. Vet. Akad. Handl. 21: 217. 1800

18 species (Kurzweil et al., 1991; Hunt, 1968).

Corycium Swartz, Kongl. Vet. Akad. Handl. 21: 220. 1800 .

14 species (Kurzweil et al., 1991).

\section{Key to the Genera in the Diseae}

la. Column-part elongated; petals and sepals rather similar (Satyriinae)

2a. Lip with two spurs, these sometimes reduced to saccae or rarely lost; lip galeate or hood forming.

3a. Viscidium solitary; stigma pulvinate

3b. Viscidia usually paired; stigma flaplike

Satyridium

b. Lip scarcely different from the petals and never spurred.

4a. Lip with small side lobes

4b. Lip without small side lobes

Pachites bodkini

Pachites appressa

lb. Column-part short or missing; petals and sepals generally quite different.

5a. Petals spathulate; the margins deeply fimbriate; anther cells diverging (Huttonaeinae) _............... Huttonaea

5b. Petals not spathulate, entire or lobed (Coryciinae and Brownleeinae).

6a. Petals adnate to the dorsal sepal to form a galea; lip ascending at the base and appressed to the stigma.

7a. Lateral sepals spurred or saccate

Disperis

7b. Lateral sepals never spurred or saccate.

8a. Dorsal sepal spurred Brownleea

8b. Dorsal sepal never spurred.

9a. Lip-blade anchor-shaped, rarely rhomboid or reniform.

10a. Lip with a prominent callus

Ceratandra

10b. Lip without a callus

Evotella

9b. Lip blade not anchor-shaped.

1 la. Dorsal sepal and petals forming a deeply globose hood ................................ Corycium

l lb. Dorsal sepal and petals forming a shallow to flat galea ………….......... Pterygodium

6b. Petals free from the dorsal sepal; lip never appressed to the stigma and generally patent at the base.

12a. Lip complex, with an ascending basal part, flat middle part, and toothlike apex ...... Schizodium 12b. Lip simple, rarely lobed or fimbriate.

13a. Viscidium solitary or rarely paired; petals and lip fleshy; rostellum consisting only of a massive central lobe

Monadenia

13b. Viscidia paired or rarely fused; petals and lip not fleshy; rostellum two- or three-lobed.

14a. Lip ovate, sessile or spathulate, the margins often fimbriate or lobed; petals strongly falcate; leaves grasslike Herschelianthe

14b. Plants not as above Dis

\section{Literature Cited}

BarthlotT, W. 1976. Morphologie der Samen von Orchideen im Hinblick auf taxonomische und funktionelle Aspekte. Proceedings of the Eighth World Orchid Conference 1976: 444-455.

Bentham, G. \& J. D. Hooker. 1883. Genera Plantarum, vol. 3. L. Reeve, London.

Bolus, H. 1882. Notes on some Cape orchids. J. Linn Soc., Bot. 19: 233-238.
- 1888. The orchids of the Cape Peninsula Trans. S. African Philos. Soc. 5: 1-201.

- 1893-1896. Icones Orchidearum Austro-Africanarum Extratropicarum, Vol. 1. Wesley \& Son, London

- 1911. Icones Orchidearum Austro-Africanarum Extratropicarum, Vol. 2. Wesley \& Son, London.

1913. Icones Orchidearum Austro-Africana- 
rum Extratropicarum, Vol. 3. Wesley \& Son, London.

1918. The orchids of the Cape Peninsula, ed. 2. Darter Bros., Cape Town.

Burns-BalOGH, P. 1983. A theory on the evolution of the exine in the Orchidaceae. Amer. J. Bot. 70: 1304-1312.

- \& V. A. FunK. 1986. A phylogenetic analysis of the Orchidaceae. Smithsonian Contr. Bot. 61: 179.

Carpenter, J. M. 1988. Choosing among multiple equally parsimonious cladograms. Cladistics 4: 291296.

Chase, M. W. \& J. S. Pippen. 1988. Seed morphology in the Oncidiinae and related subtribes (Orchidaceae). Syst. Bot. 13: 313-323.

Chesselet, P. C. 1989. Systematic Implications of Leaf Anatomy and Palynology in the Disinae and Coryciinae (Orchidaceae). M.Sc. Thesis, University of Cape Town.

— \& H. P. LindER. 1993. Pollen morphology of the Diseae (Orchidoideae; Orchidaceae). Grana 32: $101-110$.

Clifford, H. T. \& W. K. Smith. 1969. Seed morphology and classification of Orchidaceae. Phytomorphology 19: 133-139.

DARwin, C. 1888. The Various Contrivances by which Orchids are Fertilised by Insects, 2nd ed. John Murray, London.

Dressler, R. L. 1979. The subfamilies of the Orchidaceae. Selbyana 5: 197-206.

- 1981. The Orchids - Natural History and Classification. Harvard Univ. Press, Cambridge, Massachusetts, and London.

- 1986. Recent advances in orchid phylogeny. Lindleyana $1: 5-20$

. 1990. The Neottieae in orchid classification. Lindleyana 5: 102-109.

FARRIS, J. S. 1969. A successive approximations approach to character weighting. Syst. Zool. 18: 374385.

-. 1988. Hennig86 Reference. Published privately.

Felsenstein, J. 1985. 1988. Confidence limits on phylogenies: An approach using the bootstrap. Evolution 39: 783-79l.

FUnK, V. A. 1982. The systematics of Montanoa (Asteraceae, Heliantheae). Mem. New York Bot. Gard. 36: $1-133$.

- 1985a. Phylogenetic patterns and hybridization. Ann. Missouri Bot. Gard. 72: 681-715.

- 1985b. Cladistics and generic concepts in the Compositae. Taxon 34: 72-80.

Hall, A. V. 1982. A revision of the southern African species of Satyrium. Contrib. Bolus Herb. 10: 1137.

Healey, P. L., J. D. Michaud \& J. Arditti. 1980. Morphometry of orchid seeds. III. Native California and related species of Goodyera, Piperia, Platanthe$r a$ and Spiranthes. Amer. J. Bot. 67: 508-519.

Humphries, C. J. 1981. Cytogenetic and cladistic studies in Anacyclus L. (Compositae: Anthemideae). Nordic J. Bot. 1: 83-96.

Hunt, P. F. 1968. Pterygodium, Orchidaceae, part l. Pp. 216-230 in E. Milne-Redhead \& R. M. Polhill (editors), Flora of Tropical East Africa. Crown Agents for Oversea Governments and Administrations, London.
KaPlan, D. R. 1975. Comparative developmental evaluation of the morphology of unifacial leaves in the monocotyledons. Bot. Jahrb. Syst. 95: 1-105.

Kraenzlin, F. 1899-1900. Orchidacearum Genera et Species. Mayer \& Müller, Berlin.

KurzweIL, H. 1987a. Developmental studies in orchid flowers. I: Epidendroid and vandoid orchids. Nordic J. Bot. 7: 427-442.

. 1987b. Developmental studies in orchid flowers. II: Orchidoid species. Nordic J. Bot. 7: 443451.

- 1988. Developmental studies in orchid flowers. III: Neottioid species. Nordic J. Bot. 8: $271-$ 282.

. 1989. Floral morphology and ontogeny in Huttonaea pulchra. Lindleyana 4: 1-5.

-. 1990. Floral morphology and ontogeny in Orchidaceae subtribe Disinae. J. Linn. Soc., Bot. 102: 61-83.

- 1991. The unusual structure of the gynostemium in the Orchidaceae-Coryciinae. Bot. Jahrb. Syst. 112: 273-293.

- 1993a. The remarkable anther structure of Pachites bodkinii (Orchidaceae). Bot. Jahrb. Syst. 1 14: 56l-569.

- 1993b. Seed morphology in southern African Orchidoideae (Orchidaceae). Pl. Syst. Evol. 185: 229 247.

— \& H. P. LindER. 1991. A comparative study of the floral morphology in the genus Disperis (Orchidaceae). Beitr. Biol. Pflanzen 66: 433-477.

- \& P. Chesselet. 1991. The phy logeny and evolution of the Pterygodium-Corycium complex (Coryciinae, Orchidaceae). Pl. Syst. Evol. 175: 161-223.

LiNDER, H. P. 1981a. Taxonomic studies on the Disinae: 1. A revision of the genus Brownleea Lindl. J. S. African Bot. 47: 13-48.

— $1981 \mathrm{~b}$. Taxonomic studies on the Disinae: 2 . A revision of the genus Schizodium Lindl. J. S African Bot. 47: 339-371.

- 1981c. Taxonomic studies on the Disinae. III. A revision of Disa Berg. excluding sect. Micranthae Lindl. Contrib. Bolus Herb. 9: 1-370.

- 1981d. Taxonomic studies in the Disinae. V. A revision of the genus Monadenia Lindl. Bothalia 13: 339-363.

- 1981e. Taxonomic studies in the Disinae. VI. A revision of the genus Herschelia Lindl. Bothalia 13: $365-388$

- 1981f. Taxonomic studies in the Disinae. IV. A revision of Disa Berg. sect. Micranthae Lindl. Bull. Jard. Bot. Natl. Belg. 5l: 255-346.

- 1985 Notes on the orchids of southern tropical Africa. I: Brownleea and Herschelia. Kew Bull. 40 $125-129$.

- 1986 Notes on the phylogeny of the Orchidoideae, with particular reference to the Diseae. Lindleyana 1: 5l-64.

- 1989. Satyridium rostratum. Fl. Pl. Africa 50: pl. 1993.

1991. Confidence limits in phylogenies: An example from the African Restionaceae. Taxon 40: $253-266$.

\& H. KuRzweil. 1990. Floral morphology and phylogeny of the Disinae (Orchidaceae). J. Linn. Soc., Bot. 102: 287-302. 
Lindley, J. 1830-1840. Genera and Species of Orchidaceous Plants. Ridgeways, London.

Manning, J. C. \& H. P. Linder. 1992. Pollinators and evolution in Disperis (Orchidaceae), or why are there so many species? S. African J. Sci. 88: 38-49.

Marloth, R. 1895. The fertilisation of Disa uniflora Berg. by insects. Trans. S. African Philos. Soc. 8: xciii-xcv.

Pfitzer, E. 1889. Orchidaceae. In: A. Engler \& K. Prantl (editors), Die Natürlichen Pflanzenfamilien 2(6): 53-96. Engelmann, Leipzig.

Phipps, J. B., K. R. Roberson, J. R. Rohrer \& P. G. SMITH. 1991. Origins and evolution of Subfam. Maloideae (Rosaceae). Syst. Bot. 16: 303-332.

Rasmussen, F. N. 1982. The gynostemium of the neottioid orchids. Opera Bot. 65: 1-96.

Rauschert, S. 1983. Beitrag zur Nomenklatur der Orchidaceae. Feddes Repert. 94: 433-471.

Rolfe, R. A. 1898. Orchideae. In: W. T. ThiseltonDyer (editor), Flora of Tropical Africa VII: 12-292.

—. 1912-1913. Orchidaceae. In: W. T. Thiselton-Dyer (editor), Flora Capensis, Vol. V, Sect. 3. L. Reeve, London.

Rudall, P. 1990. Comparative leaf morphogenesis in Iridaceae. Bot. Jahrb. Syst. 1 12(2): 141-260.

Sanderson, M. J. 1989. Confidence limits on phylogenies: The bootstrap revisited. Cladistics 5: 113-129.

Schelpe, E. A. 1966. An Introduction to the South African Orchids. Purnell \& Sons, Cape Town, Johannesburg.

Schill, R. \& W. Pfeiffer. 1977. Untersuchungen an Orchideenpollinien unter besonderen Berücksichtigung ihrer Feinskulpturen. Pollen \& Spores 19: 5118.

SchlechteR, R. 1898. Monographie der Disperideae. Bull. Herb. Boissier ser. 1, 6: 800-821, 846-859, 905-955.

- 1901. Monographie der Diseae. Bot. Jahrb. Syst. 31: 134-313.

. 1926. Das System der Orchidaceen. Notizbl. Bot. Gart. Berlin-Dahlem 9: 563-59l.

Senchas, K. 1973-1974. Orchidoideae. In: F. G. Brieger, R. Maatsch \& K. Senghas. 197lff., Die Orchideen. Rudolf Schlechter, 3rd ed. Berlin, Hamburg.

Steiner, K. M. 1989. The pollination of Disperis (Orchidaceae) by oil-collecting bees in southern Africa. Lindleyana 4: 164-183.

Stevens, P. F. 1985. The genus concept in practiceBut for what practice? Kew Bull. 40: 457-465.

- 1991. Character states, morphological variation, and phylogenetic analysis: A review. Syst. Bot. 16: 553-583.

Stewart, J., H. P. Linder, E. A. Schelpe \& A. V. Hall. 1982. Wild Orchids of Southern Africa. MacMillan South Africa, Johannesburg.
Summerhayes, V. S. 1968. Orchidaceae (Part 1). In: E. Milne-Redhead \& R. M. Polhill (editors), Flora of Tropical East Africa. Crown Agents for Oversea Governments and Administrations, London.

Swartz, O. 1800. Orchidemes slagter orch arter upstallde. Kongl. Vetense. Acad. Nya Handl. 31: 202254.

Swofford, D. L. 1993. PAUP: Phylogenetic Analysis Using Parsimony, Version 3.1. A User's Manual. Illinois Natural History Survey, Champaign.

SzlachetKo, D. L. 1991. New taxa within the order Orchidales. Folia Geobot. Phytotax. 26: 315-329.

ToнDA, T. 1983. Seed morphology in Orchidaceae I. Dactylorchis, Orchis, Ponerorchis, Chondradenia and Galeorchis. Sci. Rep. Tohoku Imp. Univ., Ser. 4, Biol. 38: 253-268.

Trimen, R. 1864. On the fertilization of Disa grandiflora, J. Linn. Soc., Bot. 7: 144-147.

Verdcourt, B. 1968. Disperis, Orchidaceae (part 1). Pp. 216-230 in E. Milne-Redhead \& R. M. Polhill (editors), Flora of Tropical East Africa. Crown Agents for Oversea Governments and Administrations, London.

Vogel, S. 1959. Organographie der Blüten Kapländischer Ophrydeen, mit Bemerkungen zum Koaptations-Problem. Akad. Wiss. Abh. Math.-Naturwiss. Kl. 2: 268-532.

Wagner, W. L., R. E. Stockhouse \& W. M. KLein. 1985. The systematics and evolution of the Oenothera caespitosa species complex (Onagraceae). Monogr. Syst. Bot. Missouri Bot. Gard. 12: 1-103.

Weale, M. J. P. 1873. Some observations on the fertilisation of Disa macrantha. J. Linn. Soc., Bot. 13: $45-47$.

Weber, A. 1980. Die Homologie des Perigons der Zingerberaceen. Ein Beitrag zur Morphologie und Phylogenie des Monokotylen-Perigons. Pl. Syst. Evol. 133: 14.9-179.

WerdeLIN, L. 1989. We are not out of the woods yet - A report from a Nobel symposium. Cladistics 5: 192-200.

WILDHABER, O. J. 1972. Zur Karpologie von Orchis. $I n:$ K. Senghas \& H. Sundermann (editors), Probleme der Orchideengattung Orchis. Jahresber. Naturwiss. Vereins Wuppertal 25: 61-66.

WILEY, E. O. 1981. Phylogenetics. The Theory and Practice of Phylogenetic Systematics. John Wiley \& Sons, New York.

Williamson, G. 1977. The Orchids of South Central Africa. J. M. Dent \& Sons, London.

ZIEGLER, B. 1981. Mikromorphologie der Orchideensamen unter Berücksichtigung Taxonomischer Aspekte. Ph.D. Thesis, Ruprecht Karls Universität, Heidelberg. 